\title{
PESCA MARÍTIMA EN ARGENTINA (1943-2015): SIETE DÉCADAS DE EXTRACTIVISMO
}

\author{
Pesca marítima na Argentina (1943-2015): sete décadas de extrativismo \\ Sea fishering in Argentina (1943-2015): Seven decades of extractivism \\ Pêche maritime en Argentine (1943-2015): sept décennies d'extractivisme \\ Sebastián Gómez Lende \\ Instituto de Geografía, Historia y Ciencias Sociales. CONICET/UNCPBA \\ gomezlen@fch.unicen.edu.ar
}

Artigo enviado para publicação em 20/03/2018 e aceito em 27/04/2018

DOI: $10.12957 /$ tamoios.2018.33264

\section{Resumen}

No obstante constituir una actividad extractiva de capital importancia para la alimentación, el comercio y la producción y organización social del espacio, la pesca no ha sido objeto de abordajes frecuentes desde las ciencias sociales, y menos aún desde la geografía. Siguiendo esa tendencia, sus impactos tampoco han sido analizados en profundidad por los estudios académicos sobre el modelo extractivista, actualmente tan en boga en América Latina. Buscando cubrir esa área de vacancia, este artículo describe y analiza las vicisitudes de la pesca marítima argentina durante el período 1943-2015, valiéndose para ello de bibliografía erudita especializada, estadísticas oficiales históricas, estudios independientes e información periodística. Los resultados muestran el constante avance, durante las últimas siete décadas, de una racionalidad extractivista y depredatoria basada en el creciente sesgo exportador, la extranjerización (y consiguiente pérdida de soberanía) pesquera, la debilidad regulatoria estatal, la corrupción privada e institucional, la destructiva voracidad del capital, el constante aumento de la presión sobre el recurso, el consecuente colapso biológico del mismo y la proliferación de agudos conflictos socioeconómicos, territoriales y ambientales.

Palabras-clave: pesca marítima; extractivismo; Argentina; períodos históricos.

\section{Resumo}

Não obstante constituir uma atividade extrativa de capital importância para a alimentação, o comércio e a produção e organização social do espaço, a pesca não foi sujeita a abordagens freqüentes das ciências sociais, e ainda menos da geografia. Seguindo essa tendência, seus impactos não foram analisados em profundidade pelos estudos acadêmicos sobre o modelo extrativista, atualmente muito em voga na América Latina. Procurando cobrir essa área de vaga, este artigo descreve e analisa as vicissitudes da pesca marítima argentina durante o período 1943-2015, valendo-se para isso de bibliografia especializada, estatísticas oficiais históricas, estudos independentes e informação jornalística. Os resultados mostram o avanço constante, durante as últimas sete décadas, de uma racionalidade extrativista e predatória baseada no crescente interesse exportador, a desnacionalização (e conseqüente perda de soberania) pesqueira, a fraqueza regulatória do estado, a corrupção privada e institucional, a destrutiva voracidade do capital, o constante aumento da pressão sobre o recurso, o consequente colapso biológico do mesmo e a proliferação de agudos conflitos socioeconômicos, territoriais e ambientais.

Palavras-chave: pesca marítima; extrativismo; Argentina; períodos históricos.

\begin{abstract}
Although it is an extractive activity of capital importance for human food, international trade, and social production and organization of space, fishering has not been subject to frequent approaches from social sciences, and even less from geography. According to such trend, fishering impacts neither have been analyzed in depth by the academic research on the extractivist accumulation pattern, currently so much in vogue in Latin America. By using scholarly specialized bibliography, historical official statistics, independent studies, and journalistic information, this paper seeks to cover such gap by describing and analyzing the dynamics of the Argentinean sea fishering between 1943 and 2015. Throughout the seven
\end{abstract}


decades analyzed, the results show the constant advance of an extractivist and predatory logic based on the growth of exports, the foreignization of the sector, the loss of nacional sovereignty, the State regulations' weakness, and the corporative and institutional corruption, as well as the capital's destructive voracity, the increasing pressure on the resource, the Argentinean Sea's biological collapse, and the resulting socioeconomic, territorial and environmental conflicts.

Keywords: sea fishering; extractivism; Argentina; historical periods.

\section{Resumé}

En dépit d'être une activité extractive d'importance capitale pour l'alimentation, le commerce et la production et l'organisation sociale de l'espace, la pêche n'a pas fait l'objet d'approches fréquentes des sciences sociales, et encore moins de la géographie. Suivant cette tendance, ses impacts n'ont pas été analysés en profondeur par les études académiques sur le extractivisme, actuellement très en vogue en Amérique latine. Cherchant à couvrir cette zone de vacance, cet article décrit et analyse les vicissitudes de la pêche maritime argentine au cours de la période 1943-2015, en utilisant bibliographie spécialisée, statistiques officielles historiques, études indépendantes et informations journalistiques. Les résultats montrent la progression constante, au cours des sept dernières décennies, d'une rationalité extractiviste et prédatrice basée sur la croissance des exportations, la dénationalisation (et la perte de souveraineté consécutive), la faiblesse réglementaire de l'État, la corruption privée et institutionnelle, la destructrice voracité du capital, l'augmentation constante de la pression sur la ressource et son effondrement biologique et la prolifération de conflits sociaux, économiques, territoriaux et environnementaux aigus.

Mots-clés: pêche maritime; extractivisme; Argentine; périodes historiques.

\section{INTRODUCCIÓN}

Como es bien sabido, durante la última década las investigaciones académicas sobre el impacto social, económico, político y ambiental de los usos extractivos del territorio han proliferado tanto en América Latina en general como en Argentina en particular. Sin embargo, la inmensa mayoría de tales análisis regionales y nacionales ha apuntado a lugares comunes del modelo, focalizándose, por ejemplo, en la explotación hidrocarburífera, la minería metalífera y los monocultivos de exportación. Sin perjuicio de la importancia que indudablemente esos sectores detentan dentro de la matriz extractivista, es evidente que, en términos generales, la pesca marítima -una actividad extractiva por antonomasia- ha sido en buena medida soslayada por los estudios realizados desde tal perspectiva. Este olvido es paradójicamente llamativo en el caso de Argentina, un país que es el vigésimo segundo productor mundial de pescado (FAO, 2016) y donde el sector explica el $2 \%$ del PBI, acapara el 2,9\% de las exportaciones y es el octavo complejo exportador de la economía nacional (MH-INDEC, 2017), superando incluso a rubros de larga inserción en el mercado mundial, como las carnes bovinas.

Buscando cubrir esa área de vacancia, el objetivo de este artículo consiste en describir y analizar las vicisitudes de la pesca marítima argentina a lo largo de sus diferentes momentos históricos, explicando de qué modo la actividad continuamente se ha estructurado y (re)adaptado en función de las cambiantes demandas externas durante las últimas siete décadas (1943-2015). Concretamente, se procura demostrar que, en ese marco, dicho uso del territorio ha mutado progresivamente al compás de la sistemática incorporación de una racionalidad eminentemente extractivista y depredatoria signada por el creciente sesgo exportador, la extranjerización (y consiguiente pérdida de soberanía) pesquera, la debilidad regulatoria estatal y la corrupción privada e institucional, la destructiva voracidad del capital, el constante aumento de la presión sobre el recurso, el consecuente colapso biológico del mismo y la proliferación de conflictos socioeconómicos, territoriales y ambientales. Para ello se ha recurrido a distintas fuentes, las cuales incluyen bibliografía erudita especializada, estadísticas oficiales históricas sobre los desembarques marítimos pesqueros -desagregados según años y especies capturadas-, estudios independientes e información periodística.

El trabajo se estructura de la siguiente manera. En primer lugar, se desarrolla un breve soporte teórico-conceptual que analiza la relación entre espacio geográfico y extractivismo, justifica y caracteriza la inclusión de la actividad pesquera dentro de dicho modelo de acumulación y brinda un escueto panorama de la situación del sector a nivel internacional. Comenzando el análisis empírico, el segundo apartado muestra la transición del sector pesquero argentino desde su lógica artesanal originaria a la incorporación incipiente de una racionalidad extractivista impulsada por la primera incursión significativa de la actividad en el mercado mundial: la llamada 'fiebre del tiburón' (1943-1952). Seguidamente, se aborda la extensa fase comprendida entre los años 1960 y 1989, donde se analiza la consolidación de la presencia de la pesca 
argentina en el mercado mundial de la mano de las primeras concesiones al capital extranjero, el afianzamiento de la merluza común como principal especie-objetivo, la expansión de la flota fresquera primero y congeladora después, la promoción estatal a la lógica extractiva, la incipiente asociación del empresariado nacional con firmas foráneas y los primeros atisbos de sobreexplotación del recurso ictícola a gran escala.

El cuarto acápite estudia la metamorfosis de la pesca marítima argentina durante el modelo neoliberal (1990-2001), atendiendo para ello a las reformas estructurales implementadas, la extranjerización masiva, los tratados con la Comunidad Económica Europea y la flota asiática, la debilidad regulatoria, la ilegalidad que comienza a caracterizar a la dinámica privada e institucional del sector, la intensificación del sesgo exportador -acompañada por la definitiva disociación de la explotación pesquera respecto del mercado interno-, el colapso del recurso, los conflictos desatados por dicha crisis y la consolidación de nuevas pesquerías. A continuación, se aborda la situación de la pesca argentina durante el régimen neo-desarrollista (2002-2015), verificándose la continuidad -matizada en algunos casos y agudizada en otros- de las tendencias propias de la fase anterior. Finalmente, se presentan las principales conclusiones del trabajo.

\section{SOPORTE TEÓRICO-CONCEPTUAL: ESPACIO GEOGRÁFICO, EXTRACTIVISMO Y PESCA}

Siguiendo a Santos y Silveira (2001), el objeto de interés de la geografía no es el territorio en sí mismo, sino el territorio usado en cuanto síntesis de la configuración material y la dinámica social (Santos, 1996). Así pues, en cada período histórico los usos del territorio revelan los mecanismos mediante los cuales el espacio geográfico aglutina las formas, acciones, normas, agentes, funciones, estructuras y procesos emergentes de un determinado patrón de acumulación (Santos, 1992). Salvo contadas excepciones, los usos hegemónicos del territorio de los países periféricos suelen integrar la matriz del llamado extractivismo (Gudynas, 2015), entendido como un modelo de acumulación que, basado en la explotación intensiva de grandes volúmenes de recursos naturales, el escaso o nulo grado de industrialización local, regional y/o nacional de los bienes extraídos y un sesgo predominantemente exportador orientado a satisfacer las necesidades de los países centrales, reporta siderales ganancias al capital concentrado a la vez que desencadena altos niveles de conflictividad social, económica, política, ambiental y territorial (Féliz, 2012; Seoane, 2013; Frechero, 2013; Giarracca y Teubal, 2013; Burchardt \& Dietz, 2014; Portillo Riascos, 2014; Gudynas, 2015).

Bajo el imperio de las funciones extractivas de la división internacional del trabajo, desde la época colonial hasta la actualidad el territorio ha sido usado como si de un mero recurso se tratara (Gottmann, 1975; Haesbaert, 2008), la economía de enclave ha sido la forma arquetípica hegemónica de articulación local con el mercado mundial y las regiones implicadas se han convertido en simples colonias-commodities (Machado Aráoz, 2013) donde la concentración de los recursos en pocas manos (nacionales o, más a menudo, extranjeras) y el acelerado crecimiento de las exportaciones han generado crecientes niveles de subordinación, dependencia y vulnerabilidad político-económica y destrucción socio-ambiental (Féliz, 2012). Cabe recordar que el modelo extractivista expresa procesos que, ya a comienzos del Siglo XX, geógrafos europeos como Friedrich y Brunhes habían conceptualizado bajo el rótulo de 'economías de rapiña tropical' y 'hechos de ocupación destructiva' (Brunhes, 1942; Ruiz Acosta, 2014; MassardGuilbaud, 2016). Al no satisfacer necesidades internas, los usos extractivos del territorio operan como formas representativas de lo que Marx (1968) y Santos y Silveira (2001), respectivamente, han llamado 'producción innecesaria' y 'circulación innecesaria'.

Dado que el constante avance de la racionalidad capitalista sobre nuevos territorios y bienes naturales obliga a redefinir la condición renovable o no de determinados recursos, el concepto de extractivismo se ha tornado más amplio y polisémico, superando así la estrecha definición clásica o tradicional -que lo reducía a mero sinónimo de minería y explotación hidrocarburífera- para hallarse presente también en el agronegocio y los monocultivos de exportación, la foresto-industria e incluso el turismo internacional de lujo y los mega-proyectos de infraestructura (Svampa, 2011; Gudynas, 2012; Seoane, 2013). Lo anterior bien puede ser extrapolado a otra actividad primaria asociada a la explotación de una biomasa que -en teoría y dentro de ciertos límites- es técnicamente renovable, pero donde el afán de lucro capitalista se revela incompatible con los tiempos de reposición de la naturaleza: la pesca marítima.

A pesar de ser milenaria y vital para la alimentación, la navegación y el intercambio, por regla general la pesca no ha sido objeto de abordajes frecuentes desde las ciencias sociales (Mateo, 2004), y menos aún desde la perspectiva del extractivismo. Este olvido se torna llamativo cuando se advierte que, durante los últimos setenta años, la sistemática trasgresión de los umbrales de reproducción biológica del recurso ha convertido a la actividad en una suerte de 'minería pesquera' (Cóccaro et al., 2000). La propia Organización de las Naciones Unidas para la Alimentación y la Agricultura declaró en 2012 que la situación 
de la pesca marina de captura a nivel mundial era inquietante y estaba empeorando (FAO, 2012). Seis años antes, un estudio internacional publicado en la afamada revista Science había arrojado un panorama desolador al augurar el colapso biológico de los mares hacia el año 2048. Basta señalar que, entre 1950 y 2003, el 29\% de las especies marinas colapsó, la biomasa explotable se redujo un $80 \%$, nueve de los diecisiete caladeros del mundo han sido totalmente devastados y otros cuatro enfrentan una amenaza equivalente (Maturana, 2007; Barruti, 2013).

Las razones de esta situación son evidentes. Empujada por la significativa expansión del consumo per cápita de pescado $-19,7 \mathrm{~kg}$. por habitante en 2013, contra 9,9 kg. en 1960-, la pesca marina mundial se cuadruplicó en menos de setenta años (1950-2013), pasando de extraer 16,8 millones de toneladas a 81,5 millones de toneladas (FAO, 2016). Este dramático incremento de la capacidad extractiva ha sido posible gracias al crecimiento de la flota pesquera (sobre todo, buques congeladores y factoría), la utilización de artes de pesca predatorias (redes de arrastre, cercas, etc.) y la incorporación masiva de tecnología (GPS, radares, satélites y software para la localización de cardúmenes). A esto debe agregarse la creciente pesca ilegal, que cada año representa no menos del 15\% de los desembarques mundiales totales (Telam, 2016), y el llamado 'descarte', entendido como el acto de desechar al mar a los ejemplares involuntariamente capturados cuyo tamaño y/o especie no satisfacen los requerimientos técnico-económicos de los buques. Según las escasas estadísticas disponibles, los niveles de descarte a escala mundial oscilaban entre los 27 millones de toneladas/año reportados en la década de 1990 y los 7,3 millones de toneladas anuales detectados en épocas más recientes (FAO, 2016) -es decir, entre el $9 \%$ y el 33\% de los desembarques declarados-. Esta situación se torna más grave aún cuando se recuerda que la actividad pesquera representa el $15 \%$ de la ingesta promedio de proteínas de origen animal para un tercio de la población mundial y constituye además la principal fuente proteica diaria para 90 millones de personas, en su mayoría localizadas en los países periféricos (DGN, 2011).

Obstando la implementación de reservas marinas, la única 'solución' que los organismos internacionales y las potencias pesqueras han ofrecido hasta el momento ha sido fomentar la expansión de la acuicultura, actividad que hoy día representa el 44,1\% de la producción pesquera global (FAO, 2016). No obstante, es una propuesta falaz, dado que las piscifactorías han aumentado la demanda global de harinas de pescado salvaje para alimentar a peces en cautiverio, compitiendo con el consumo humano y acelerando el ritmo de extinción de especies en peligro (Ocean Sentry.org, 2009).

\section{PRIMERA INCURSIÓN EN EL MERCADO MUNDIAL: LA FIEBRE DEL TIBURÓN (1943-1952)}

Con un litoral costero de alrededor de $5.000 \mathrm{~km}$. de longitud y una superficie de aproximadamente 1.000.000 km2, el Mar Argentino se sitúa en el Océano Atlántico Sudoccidental, formando un ecosistema templado-frío dotado de un extremadamente rico grado de biodiversidad, el cual incluye 112 especies de crustáceos, 186 moluscos y 394 peces (OPP, 2009; Mateo y Yurkievich, 2010). Esta inmensa riqueza natural fue escasamente explotada entre finales del Siglo XVIII y la primera mitad del Siglo XIX, comenzando recién a cobrar cierta importancia a partir de 1880. Con epicentro en el litoral marítimo bonaerense -puertos de Mar del Plata, Quequén y Bahía Blanca- y patagónico -destacándose sobre todo San Antonio, Puerto Madryn, Rawson, Puerto Deseado y Ushuaia- (Figura 1), la pesca costera artesanal se desarrolló al compás de la llegada de inmigrantes europeos y la escasa demanda interna de pescado fresco y productos salados y en conserva elaborados a base de anchoíta, pescadilla, róbalo, mero y corvina. A pesar de los extremadamente bajos niveles de capitalización detentados por estas unidades productivas familiares (Mateo, 2004), las capturas crecieron exponencialmente en sólo en treinta años, pasando de las 299 toneladas registradas en 1898 a las 24.069 toneladas reportadas en 1929 (Sánchez, Navarro y Rozicky, 2012). 
Figura 1. Litoral marítimo bonaerense y patagónico (principales puertos). República Argentina.

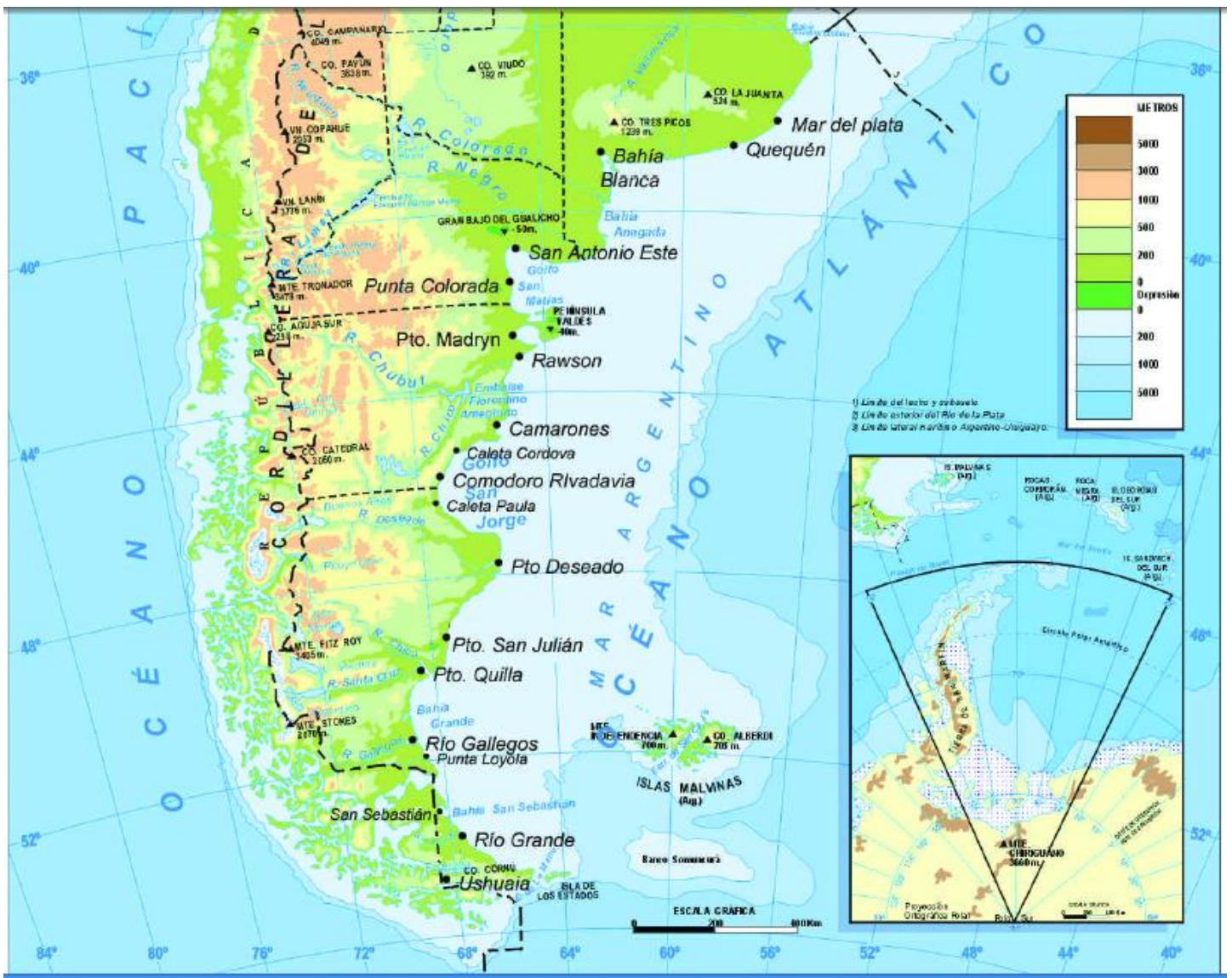

Fuente: AA (s/f).

Lejos de resultar adversa, la crisis internacional de 1929 alentó la expansión del sector pesquero argentino. Sin embargo, el verdadero punto de inflexión se produjo durante la década de 1940, cuando la Segunda Guerra Mundial propició la eclosión de la llamada 'fiebre del tiburón'. Cuando el conflicto bélico bloqueó el acceso a los caladeros tradicionales (Terranova, Mar del Norte, Mar del Japón) y Estados Unidos no pudo continuar importando aceite de hígado de bacalao para satisfacer sus necesidades internas de consumo vitamínico, el esfuerzo pesquero se reorientó hacia especies cuyo hígado poseía altas concentraciones vitamínicas A y D, como los tiburones de las variedades 'cazón', 'escalandrum', 'bacota', 'perro' y 'martillo'. La propia logística de la guerra coadyuvó a incrementar sustancialmente la demanda de las citadas vitaminas, necesarias para aguzar la visión en la oscuridad y combatir la pre-ceguera nocturna de los aviadores y conductores de lanchas de asalto de los Países Aliados. Como resultado, esta pesquería se propagó rápidamente en Australia y Sudáfrica, difundiéndose más tarde en Brasil, Uruguay y Argentina (Mateo, 2006; Mateo, Nieto y Colombo, 2010).

Debido a la meteórica alza de los precios -en 1937, la tonelada valía entre 40 y 60 dólares, mientras que en 1941 ya ascendía a 2.000 dólares-, la pesca del tiburón se convirtió en la más lucrativa de la época, generando a partir de 1943 una masiva y espontánea adhesión en Mar del Plata. Otrora considerado como una plaga que competía con los pescadores en la captura de las especies-objetivo habituales, el tiburón repentinamente se convirtió en un producto codiciado que tenía una tasa de utilidad comparable casi a la del ganado bovino, debido no sólo a la extracción del cotizado aceite hepático, sino también a su aprovechamiento integral para la salazón y secado de su carne en conserva, la elaboración de harinas, la utilización de su cuero en la confección de calzado y carteras e incluso la venta de sus vísceras para la extracción de colas y gelatinas (Mateo, 2006). Superando ampliamente a especies costeras tradicionales y registrando volúmenes superiores a los obtenidos por la ya consolidada pesquería de la merluza común, las capturas de las distintas variedades de escualos -prácticamente despreciables al inicio de la Segunda Guerra Mundial- crecieron 5,7 veces durante el bienio 1943-1944, pasando de 1.807,5 toneladas a 10.310,3 toneladas y llegando a representar en ese último año la cuarta parte de los desembarques totales (Cuadro 1). Orientadas preferentemente a Estados Unidos, Francia y el Reino Unido, las exportaciones argentinas de los distintos productos elaborados en base a esta especie alcanzaron su pico máximo en 1946, llegando a las 273.185 toneladas (Mateo, 2006). 
Cuadro 1. Volumen de desembarques de pescado en puertos marítimos (en toneladas y porcentajes). Principales especies y años seleccionados. Argentina, 1939-1952

\begin{tabular}{|l|c|c|c|c|c|c|}
\hline Especie & $\mathbf{1 9 3 9}$ & $\mathbf{\%}$ & $\mathbf{1 9 4 4}$ & $\mathbf{\%}$ & $\mathbf{1 9 5 2}$ & \% \\
\hline Anchoíta & $4.150,1$ & 12,00 & $5.961,3$ & 14,51 & $6.608,2$ & 9,82 \\
\hline Caballa & s/d & ---- & s/d & ---- & $17.957,9$ & 26,69 \\
\hline Cornalito & $1.284,9$ & 3,72 & 896,8 & 2,18 & 767,2 & 1,14 \\
\hline Corvina blanca & $4.873,9$ & 14,09 & $5.424,9$ & 13,21 & $3.978,0$ & 5,91 \\
\hline Merluza común & $\mathbf{1 2 . 0 1 9 , 4}$ & $\mathbf{3 4 , 7 6}$ & $\mathbf{1 0 . 1 8 3 , 4}$ & $\mathbf{2 4 , 7 9}$ & $\mathbf{2 4 . 6 2 4 , 3}$ & $\mathbf{3 6 , 6 0}$ \\
\hline Pescadilla & $4.546,9$ & 13,15 & $5.822,6$ & 14,17 & $2.737,8$ & 4,07 \\
\hline Tiburón & $\mathbf{2 6 , 2}$ & $\mathbf{0 , 0 8}$ & $\mathbf{1 0 . 3 1 0 , 3}$ & $\mathbf{2 5 , 1 0}$ & $\mathbf{1 . 4 2 1 , 1}$ & $\mathbf{2 , 1 1}$ \\
\hline Sub-total & $\mathbf{2 6 . 9 0 1 , 4}$ & $\mathbf{7 7 , 8 0}$ & $\mathbf{3 8 . 5 9 9 , 3}$ & $\mathbf{9 3 , 9 7}$ & $\mathbf{5 8 . 0 9 4 , 5}$ & $\mathbf{8 6 , 3 6}$ \\
\hline Resto & $7.678,6$ & 22,20 & $2.481,2$ & 6,03 & $9.183,0$ & 13,64 \\
\hline Total & $\mathbf{3 4 . 5 8 0 , 0}$ & $\mathbf{1 0 0 , 0 0}$ & $\mathbf{4 1 . 0 8 0 , 5}$ & $\mathbf{1 0 0 , 0 0}$ & $\mathbf{6 7 . 2 7 7 , 5}$ & $\mathbf{1 0 0 , 0 0}$ \\
\hline
\end{tabular}

Fuente: elaboración personal sobre la base de Sánchez, Navarro y Rozycki (2012).

Si bien relativamente breve (1943-1952), el boom de la pesca del tiburón operó como una bisagra dentro del desarrollo de la pesca comercial marítima argentina, impulsando el sostenido crecimiento de las capturas, la fundación de astilleros, la modernización de la flota costera y la expansión de las fábricas de artes de pesca. A medida que el laboratorio estadounidense Washington radicaba filiales para extraer vitaminas del aceite de hígado de tiburón, pescadores retirados y novatos, neófitos y hasta jóvenes universitarios abandonaron sus actividades habituales para lanzarse a la fiebre en curso y así acumular en una sola temporada suculentas rentas que con sus profesiones sólo hubieran conseguido tras largos años de trabajo. En ese contexto, hasta yates de lujo acabaron convirtiéndose en barcos 'cazoneros' (Siccardi, 1950; López, 1954).

El auge fue efímero y el tiburón se convirtió en la primera especie del Mar Argentino sometida a sobre-pesca, quedando incluso al borde de la extinción. Lejos de los picos históricos alcanzados en 1944 en la costa marplatense, cuando se desembarcaron 3.000 tiburones en un solo día, su pesca comenzó a escasear, obligando a realizar incursiones en el sur bonaerense y las costas patagónicas. Como resultado, y ante la inacción del Estado, los propios pescadores elaboraron un proyecto de ley para vedar la captura de esta especie. Por añadidura, la racionalidad extractivista de la época rápidamente perdió impulso debido a la consolidación de la paz mundial primero y la síntesis de la vitamina A por parte del laboratorio suizo Roche después (Mateo, 2006). Como resultado, hacia 1952 la participación del tiburón en los desembarques nacionales se había reducido al 2,1\% (Cuadro 1), y un año después ya había desaparecido como rubro de exportación.

\section{BOOM DE HARINAS Y CONGELADOS Y PRIMERAS CONCESIONES AL CAPITAL EXTRANJERO: 'CICLO PERUANO', AUGE DE LA MERLUZA Y RESIGNACIÓN DE SOBERANÍA (1960-1989)}

Concluida la fiebre del tiburón, los ritmos de la actividad pesquera volvieron a ser marcados por los desembarques de la clásica anchoíta y la relativamente nueva pesquería de la caballa con destino a la ya consolidada industria conservera. Sin embargo, la alianza urdida entre el Estado nacional, la burguesía industrial y las fuerzas militares suplantaría al antiguo proyecto populista por un nuevo modelo que, basado en el reformismo desarrollista, afianzaría la inserción del sector pesquero argentino en el mercado mundial y permitiría la incipiente penetración del capital extranjero. En el marco del llamado 'ciclo pesquero peruano' (1956-1970), el Estado procuró incorporar al país a una coyuntura signada por la creciente demanda internacional de harinas y aceites de pescado para la elaboración de alimentos balanceados para consumo animal. Para ello, en 1966 el gobierno argentino permitió por primera vez el ingreso de flotas extranjeras al Mar Argentino, firmando tratados con la Unión Soviética (sobre todo con Polonia) para la extracción de castañeta (Madaria, 1999; INAP, 1999; OPP, 2009).

El boom y posterior casi extinción de esta especie configuraron el segundo episodio del proceso de reorientación del sector hacia los mercados internacionales e inserción de nuestro país en la tendencia global de propagación de la lógica de la pesca industrial a gran escala. Los buques rusos y polacos arrasaron con el recurso: de hecho, las capturas de castañeta crecieron 298 veces en apenas siete años, pasando de las apenas 228,2 toneladas registradas en 1960 al pico histórico máximo de 68.092,3 toneladas reportado en 1966, año en el cual dicha especie lideró los desembarques (32,26\%). Sin embargo, a partir de entonces la depredación llevada a cabo por la flota soviética determinó un constante descenso de las capturas de castañeta, las cuales se desplomaron un 93,21\% entre 1966 y 1975, pasando a explicar apenas el 2,32\% de los desembarques (Cuadro 2). 
Cuadro 2. Volumen de desembarques de pescado en puertos marítimos (en toneladas y porcentajes). Principales especies y años seleccionados. Argentina, 1960-1975

\begin{tabular}{|l|c|c|c|c|c|c|}
\hline Especie & $\mathbf{1 9 6 0}$ & $\mathbf{\%}$ & $\mathbf{1 9 6 6}$ & $\mathbf{\%}$ & $\mathbf{1 9 7 5}$ & \% \\
\hline Anchoíta & $11.177,6$ & 13,13 & $10.978,0$ & 5,20 & $19.155,4$ & 9,62 \\
\hline Caballa & $15.020,1$ & 17,63 & $16.130,1$ & 7,64 & $8.921,2$ & 4,48 \\
\hline Calamar illex & 567,9 & 0,67 & $1.031,2$ & 0,49 & $4.131,5$ & 2,07 \\
\hline Castañeta & $\mathbf{2 2 8 , 2}$ & $\mathbf{0 , 2 7}$ & $\mathbf{6 8 . 0 8 9 , 3}$ & $\mathbf{3 2 , 2 6}$ & $\mathbf{4 . 6 1 9 , 9}$ & $\mathbf{2 , 3 2}$ \\
\hline Mejillón & $4.284,9$ & 5,03 & $5.865,0$ & 2,78 & $4.421,9$ & 2,22 \\
\hline Merluza común & $\mathbf{3 6 . 0 9 4 , 6}$ & $\mathbf{4 2 , 3 8}$ & $\mathbf{6 8 . 4 9 8 , 1}$ & $\mathbf{3 2 , 4 5}$ & $\mathbf{1 0 8 . 9 9 2 , 1}$ & $\mathbf{5 4 , 7 5}$ \\
\hline Pargo & 512,8 & 0,60 & $7.515,5$ & 3,56 & $9.692,8$ & 4,87 \\
\hline Sub-total & $\mathbf{6 7 . 8 8 6 , 1}$ & $\mathbf{8 4 , 7 4}$ & $\mathbf{1 7 8 . 1 0 7 , 2}$ & $\mathbf{8 4 , 3 8}$ & $\mathbf{1 5 9 . 9 3 4 , 8}$ & $\mathbf{8 0 , 3 3}$ \\
\hline Resto & $17.274,1$ & 15,26 & $32.958,9$ & 15,62 & $39.132,2$ & 19,67 \\
\hline Total & $\mathbf{8 5 . 1 6 0 , 2}$ & $\mathbf{1 0 0 , 0 0}$ & $\mathbf{2 1 1 . 0 6 6 , 1}$ & $\mathbf{1 0 0 , 0 0}$ & $\mathbf{1 9 9 . 0 6 7 , 0}$ & $\mathbf{1 0 0 , 0 0}$ \\
\hline
\end{tabular}

Fuente: elaboración personal sobre la base de Sánchez, Navarro y Rozycki (2012).

Con el fin del ciclo pesquero peruano, la desaceleración de la pesca a escala mundial y la caída de las pesquerías dinámicas más recientes, países con dieta pobre en carnes rojas (Rusia, Japón, Hungría, Bulgaria, España, Italia, etc.) detectaron el gran valor energético y proteico de la merluza y procuraron transferir el esfuerzo pesquero hacia los caladeros sub-explotados de los países periféricos (Mateo y Yurkievich, 2010). A raíz de esta demanda, dicho recurso se convirtió en el objetivo central de la industria pesquera nacional, de la mano de la introducción del filete de merluza, el auge de la elaboración de productos frescos y congelados y el predominio de la flota fresquera. Nació así la gran planta de fileteado y congelado, fenómeno activamente impulsado por el Estado nacional, quien generó una clase capitalista extremadamente parasitaria (Pradas, 2006) al beneficiar a los grandes armadores con créditos 'blandos', exenciones y/o reducciones fiscales y diferimientos impositivos para que refinanciaran sus pasivos comerciales y bancarios, adquirieran bienes de capital, se radicaran en tierra firme e integraran la función extractiva con la industrialización y la comercialización.

Dado que la crisis del bacalao en el Mar del Norte obligó a las potencias pesqueras tradicionales a incursionar en caladeros más lejanos utilizando buques procesadores congeladores de gran porte, el exceso (y consiguiente abaratamiento) de barcos fresquero ${ }^{1}$ en Asia y Europa fue capitalizado por varios países periféricos, entre ellos Argentina. En el marco de su nueva política pesquera, el gobierno nacional financió la incorporación y/o construcción de barcos de mayor capacidad de captura, subsidió a los astilleros nacionales y liberalizó la importación de buques nuevos y usados a precios bajos. Como resultado, mientras que en 1959 existían 338 buques costeros y prácticamente ninguno de altura, a comienzos de la década de 1970 la flota fresquera ya sumaba 152 embarcaciones y acaparaba el 58\% de los desembarques (Bertolotti, Piergentili y Cabut, 1987; Bertolotti et al., 2001; Mateo y Yurkievich, 2010).

Conforme el pescado fresco y congelado iba desplazando a las conservas, el sector profundizaba su otrora incipiente sesgo exportador, consolidando silenciosamente a la Argentina como país pesquero ligado al mercado mundial con escasa o nula regulación de la biomasa extraída (Mateo y Yurkievich, 2010). De hecho, las remesas de pescado congelado al exterior aumentaron exponencialmente durante el sexenio 1969-1974, pasando de 2 millones de dólares a 35 millones de dólares (Bertolotti, Piergentili y Cabut, 1987). A pesar de la intensa crisis económica que aquejó al sector durante el trienio 1973-1975 -aumento de la cotización internacional del petróleo, inflación del dólar, fuerte endeudamiento, sustitución coyuntural de la merluza por el pollock en los mercados internacionales, acumulación de stocks, ventas a pérdida, obsolescencia de la flota-, durante el período 1960-1975 los desembarques de merluza común se triplicaron, explicando entre casi la tercera parte y más de la mitad de las capturas (Cuadro 2).

Sin perjuicio de lo anterior, en términos generales esa expansión no ejercía aún una presión sobre el recurso pesquero lo suficientemente significativa como para comprometer su renovación. El punto de inflexión lo marcó el golpe de Estado de 1976, que precipitó el ocaso del modelo desarrollista e inauguró un patrón de acumulación regido por el pensamiento neoliberal y basado en la valorización financiera, la mayor presencia del capital extranjero, la apertura importadora, el acelerado endeudamiento externo, la desindustrialización y reprimarización de la matriz productiva, la concentración, centralización y transnacionalización del capital y el auge de las exportaciones de commodities. Si bien posteriormente la restauración democrática de 1983 pondría fin a la experiencia neoliberal promoviendo un tibio resurgimiento de la industria y el Estado del bienestar, la lógica extractivista heredada del gobierno militar se profundizaría, y definitivamente Argentina dejaría de ser un 'país con pesca' para convertirse en un verdadero 'país pesquero' (Mizrahi, 2001, citado por Colombo, 2014).

En consonancia con lo dispuesto por el Acta Final de la Convención de las Naciones Unidas sobre Derecho del Mar, en 1973 el Estado nacional ya había proclamado la exclusividad del área de 12 millas 
marinas para la flota nacional y había decretado la propiedad y potestad estatal sobre todos los recursos vivos existentes en el Mar Argentino, estableciendo una Zona Económica Exclusiva (ZEE) de 200 millas marinas dentro de la cual otorgaba permisos de pesca sólo a embarcaciones de pabellón nacional. Sin embargo, esta suerte de afianzamiento de la soberanía pesquera argentina se convirtió rápidamente en una oportunidad para que el capital extranjero aumentara su presencia en el caladero nacional. Al garantizar la apropiación jurídica y la plena vigencia de los derechos patrimoniales de los países ribereños sobre los respectivos bordes oceánicos, el nuevo orden jurídico internacional perjudicó a las potencias pesqueras con escasa costa marítima, lo cual propició el desabastecimiento de los mercados tradicionales. Como resultado, la URSS, Polonia, España, Japón y Corea del Sur fueron compensadas con la posibilidad de acordar regímenes de licencias de pesca con los países ribereños dentro de las respectivas aguas territoriales y negociar la regulación de las capturas de las especies migratorias o transzonales en el área adyacente a la ZEE (Madaria, 1999, Cóccaro et al., 2000). Desguazando con subsidios estatales sus barcos más antiguos, vendiendo los buques excedentes y asociándose a los armadores de otros países, las grandes potencias pesqueras ejercieron una fuerte presión para que los países periféricos importaran buques congeladores asiáticos y europeos, o bien anexaran barcos activos a sus propias flotas a través de la creación de empresas mixtas (Bertolotti et al., 2001; Cepparo et al., 2008; Mateo y Yurkievich, 2010).

Como resultado, el Estado nacional facilitó la importación de buques y/o su cambio de bandera, brindando exenciones impositivas y asistencia financiera -créditos, avales, reintegros impositivos, prefinanciación de las exportaciones, etc.- y promoviendo la asociación del empresariado local con el capital extranjero mediante fusiones, sociedades mixtas y Uniones Transitorias de Empresas (UTE's) donde las flotas extranjeras podían controlar hasta el 49\% del capital (Madaria, 1999; INAP, 1999; Pradas, 2006; Mateo y Yurkievich, 2010). Con la llegada de la flota congeladora extranjera, grupos exportadores se radicaron en el sur patagónico al abrigo de beneficios y franquicias especiales, exenciones fiscales, reducciones impositivas y reembolsos a las exportaciones. En contrapartida de todas estas generosas ventajas, el Estado obtenía un canon de sólo el 3\% del valor de producción, en tanto que la inmensa mayoría de los créditos otorgados por la banca pública jamás fue devuelta (Cóccaro et al., 2000).

La reestructuración previamente comentada explica el importante incremento del esfuerzo pesquero durante esta fase. La flota industrial, que en 1975 contaba con 123 embarcaciones, en 1979 ya estaba integrada por 160 buques, y en 1988, por 222, lo cual determinó que la capacidad de captura creciera un $153 \%$. Si hasta 1974 los desembarques de la flota de altura habían correspondido en su totalidad a buques fresqueros, durante el período 1979-1988 los barcos procesadores-congeladores concentraron poco más de la tercera parte (Bertolotti et al., 2001; Mateo y Yurkievich, 2010). Concomitantemente, la flota se diversificó conforme las artes de pesca se especializaban dentro del sub-sector congelador. Así, a los tradicionales barcos arrastreros se añadieron los buques poteros (para la captura de calamar), tangoneros (para la cosecha del langostino), palangreros (para la pesca de abadejo y merluza negra y austral) y factorías o surimeros (para la captura de polaca y la producción de surimi ${ }^{2}$ ).

Sin perjuicio de su aliento a la formación sociedades mixtas entre firmas pesqueras argentinas y foráneas, el Estado también fomentó la extranjerización del recurso a través de permisos especiales, tratados internacionales y acuerdos bilaterales. Se destacan, por ejemplo: a) los cupos de explotación experimental otorgados al sur del paralelo $40^{\circ}$ a flotas europeas y asiáticas; b) la adjudicación de la extracción de hasta 200.000 toneladas al sur del paralelo $42^{\circ}$; c) la cesión de licencias de pesca a 40 barcos congeladores foráneos para la captura de merluza y bacalao al sur del paralelo $47^{\circ}$; y d) la entrega de permisos de captura para distintas especies a pequeños empresarios nacionales asociados con empresas rusas, polacas, españolas, japonesas, noruegas y coreanas. Paralelamente, buques españoles, japoneses, coreanos, taiwaneses y polacos operaban libremente en el límite de la ZEE, destacándose la flota potera nipona, que literalmente arrasó con el calamar en la milla 201 (INAP, 1999; OPP, 2009).

Asimismo, se ratificó el Acuerdo del Río de La Plata y su Frente Marítimo entre Argentina y Uruguay, que estableció una Zona Común de Pesca que admitió la operación de las flotas de ambos países hasta el límite con Brasil. Al no fijarse cupos de captura precisos, este acuerdo benefició sobre todo a los buques uruguayos, que quedaron en libertad de extra-limitarse en la explotación del recurso (Madaria, 1999).

Finalmente, en 1986 el gobierno nacional firmó sendos Acuerdos Marco en materia pesquera con la Unión Soviética y Bulgaria, otorgándoles permisos de pesca dentro de la ZEE al sur del paralelo $41^{\circ}$ para la captura de calamar y polaca por un plazo de cuatro años, con cupos de 180.000 toneladas para los buques soviéticos y de 80.000 toneladas para los búlgaros. Estos acuerdos resultaron extremadamente gravosos para la soberanía pesquera argentina, dado que ninguno de los términos pactados se cumplió: no se contrató fuerza laboral nacional, no existió transferencia tecnológica y la materia prima extraída tampoco fue procesada en tierra. Por añadidura, las capturas de la flota búlgara y soviética fueron equivalentes a un $350 \%$ y un $154 \%$ de los cupos asignados, respectivamente (Bertolotti, Piergentili y Cabut, 1987; OPP, 2009; Mateo y Yurkievich, 2010). Esta expoliación queda reflejada en el Cuadro 3, donde es posible apreciar que la polaca, 
una especie que a mediados de la década de 1970 ni siquiera figuraba en los desembarques y cuya participación en los mismos era despreciable en los años previos a los Acuerdos Marco, pasó a convertirse en el segundo pez más capturado, a tal punto que sus desembarques crecieron 71 veces entre 1984 y 1989. Cabe también señalar que los buques tanto soviéticos como búlgaros sobre-explotaron la merluza y el bacalao austral, dos especies no contempladas en los convenios rubricados (Lerena, 2013). En virtud de este nutrido acervo de trasgresiones e irregularidades, el gobierno nacional decidió en 1989 poner fin prematuramente al convenio pesquero con Bulgaria.

Cuadro 3. Volumen de desembarques de pescado en puertos marítimos (en toneladas y porcentajes). Principales especies y años seleccionados. Argentina, 1976-1989

\begin{tabular}{|l|c|c|c|c|c|c|c|c|}
\hline Especie & $\mathbf{1 9 7 6}$ & $\mathbf{\%}$ & $\mathbf{1 9 7 9}$ & $\mathbf{\%}$ & $\mathbf{1 9 8 4}$ & $\mathbf{\%}$ & $\mathbf{1 9 8 9}$ & $\mathbf{\%}$ \\
\hline Abadejo & $\mathbf{3 . 3 6 1 , 0}$ & $\mathbf{1 , 3 1}$ & $\mathbf{6 . 7 9 3 , 0}$ & $\mathbf{1 , 2 4}$ & $\mathbf{3 . 8 9 4 , 0}$ & $\mathbf{1 , 2 7}$ & $\mathbf{2 1 . 0 9 1 , 6}$ & $\mathbf{4 , 1 9}$ \\
\hline Anchoíta & $20.424,5$ & 7,97 & $19.797,0$ & 3,60 & $9.700,0$ & 3,18 & $21.238,6$ & 4,22 \\
\hline Bacalao & $\mathrm{s} / \mathrm{d}$ & ---- & 2,3 & 0,00 & s/d & ---- & $1.186,0$ & 0,24 \\
\hline Besugo & $2.923,8$ & 1,14 & $10.171,0$ & 1,85 & $6.562,0$ & 2,15 & $5.826,3$ & 1,16 \\
\hline Caballa & 465,5 & 0,18 & 533,0 & 0,10 & $2.577,0$ & 0,84 & $8.030,4$ & 1,60 \\
\hline $\begin{array}{l}\text { Calamar } \\
\text { illex }\end{array}$ & $\mathbf{7 . 4 9 2 , 6}$ & $\mathbf{2 , 9 2}$ & $\mathbf{8 3 . 5 7 9 , 0}$ & $\mathbf{1 5 , 2 1}$ & $\mathbf{2 8 . 9 6 9 , 0}$ & $\mathbf{9 , 4 8}$ & $\mathbf{2 3 . 1 0 1 , 8}$ & $\mathbf{4 , 5 9}$ \\
\hline Castañeta & $2.931,3$ & 1,14 & $1.818,0$ & 0,33 & 52,5 & 0,01 & 359,9 & 0,07 \\
\hline $\begin{array}{l}\text { Corvina } \\
\text { blanca }\end{array}$ & $5.175,3$ & 2,02 & $4.392,0$ & 0,80 & $5.311,0$ & 1,74 & $6.079,9$ & 1,21 \\
\hline Gatuzo & $4.882,3$ & 1,91 & $4.545,0$ & 0,83 & $5.307,0$ & 1,74 & $8.357,3$ & 1,66 \\
\hline Langostino & $\mathbf{1 5 0 , 4}$ & $\mathbf{0 , 0 6}$ & $\mathbf{4 , 0}$ & $\mathbf{0 , 0 0}$ & $\mathbf{2 2 . 9 9 4 , 0}$ & $\mathbf{7 , 5 3}$ & $\mathbf{1 1 . 3 5 3 , 0}$ & $\mathbf{2 , 2 6}$ \\
\hline Lenguado & 908,6 & 0,35 & $2.248,0$ & 0,41 & $3.176,0$ & 1,04 & $9.731,5$ & 1,93 \\
\hline Mejillón & $3.723,6$ & 1,45 & $3.686,0$ & 0,67 & 375,0 & 0,12 & $2.132,5$ & 0,42 \\
\hline $\begin{array}{l}\text { Merluza } \\
\text { común }\end{array}$ & $\mathbf{1 7 4 . 9 0 5 , 4}$ & $\mathbf{6 8 , 2 6}$ & $\mathbf{3 7 0 . 8 6 0 , 0}$ & $\mathbf{6 7 , 5 0}$ & $\mathbf{1 8 3 . 2 3 3 , 0}$ & $\mathbf{5 9 , 9 8}$ & $\mathbf{2 9 8 . 6 8 3 , 7}$ & $\mathbf{5 9 , 3 4}$ \\
\hline Mero & $1.699,9$ & 0,66 & $4.877,0$ & 0,89 & $8.682,0$ & 2,84 & $14.508,5$ & 2,89 \\
\hline Pescadilla & $4.034,3$ & 1,57 & $5.728,0$ & 1,04 & $3.463,0$ & 1,13 & $10.122,2$ & 2,11 \\
\hline Polaca & $\mathbf{s} \boldsymbol{d}$ & $\mathbf{- - -}$ & $\mathbf{2 . 1 2 1 , 0}$ & $\mathbf{0 , 3 9}$ & $\mathbf{3 5 2 , 0}$ & $\mathbf{0 , 1 2}$ & $\mathbf{2 4 . 9 3 5 , 9}$ & $\mathbf{4 , 9 5}$ \\
\hline Sub-total & $\mathbf{2 3 3 . 0 7 8 , 6}$ & $\mathbf{9 0 , 9 7}$ & $\mathbf{5 2 7 . 1 5 4 , 3}$ & $\mathbf{9 5 , 9 5}$ & $\mathbf{2 8 4 . 6 4 7 , 5}$ & $\mathbf{9 3 , 1 8}$ & $\mathbf{4 6 6 . 7 3 8 , 8}$ & $\mathbf{9 2 , 7 3}$ \\
\hline Resto & $23.126,4$ & 9,03 & $22.232,7$ & 4,05 & $20.847,3$ & 6,82 & $36.571,7$ & 7,27 \\
\hline Total & $\mathbf{2 5 6 . 2 0 5 , 0}$ & $\mathbf{1 0 0 , 0 0}$ & $\mathbf{5 4 9 . 3 8 7 , 0}$ & $\mathbf{1 0 0 , 0 0}$ & $\mathbf{3 0 5 . 4 9 4 , 8}$ & $\mathbf{1 0 0 , 0 0}$ & $\mathbf{5 0 3 . 3 1 0 , 5}$ & $\mathbf{1 0 0 , 0 0}$ \\
\hline
\end{tabular}

Fuente: elaboración personal sobre la base de Sánchez, Navarro y Rozycki (2012).

Todos los factores hasta aquí explicados derivaron en una fuerte expansión de las capturas; de hecho, los desembarques se duplicaron entre 1976 y 1989, pasando de 256.205,0 toneladas a 503.310,5 toneladas (Cuadro 3). Conforme la flota extranjera ganaba presencia en aguas argentinas, se reforzaba el carácter de la merluza común como principal insumo del proceso productivo (Mateo, Nieto y Colombo, 2010), especie que lideró ampliamente los desembarques durante todo el sub-período. Sin perjuicio de lo anterior, el verdadero sostén económico de la actividad fue el langostino, cuya cosecha creció 737 veces entre 1976 y 1989, representando en 1984 sólo el 7,53\% de la carga declarada en 1984 pero nada menos que el 54\% del valor exportado (OPP, 2009; Mateo y Yurkievich, 2010). Impulsadas por una demanda internacional sostenida y con precios en alza constituida por Estados Unidos, Brasil, Europa y compradores no tradicionales como Nigeria, el sesgo exportador del sector pesquero argentino se acentuó, pasando de los 35 millones de dólares registrados en 1974 a los 300 millones de dólares reportados a finales de los años ochenta; de hecho, sólo en 1979 se exportaron 248.715 toneladas (Madaria, 1999; Bertolotti et al., 2001; Mateo y Yurkievich), es decir, casi la mitad $(45,27 \%)$ del pescado extraído del caladero nacional.

Conforme tanto la extranjerización como la exportación del recurso se profundizaban, el excesivo esfuerzo de pesca paulatinamente comenzaba a significar una amenaza para la renovación de la biomasa de algunas especies. El recientemente creado Instituto Nacional de Investigación y Desarrollo Pesquero (INIDEP) ya reportaba en 1986 que la merluza común había alcanzado su nivel de máximo rendimiento sostenible, aseveración que fue seguida por informes técnicos que daban cuenta de un progresivo deterioro del recurso y desaconsejaban el ingreso de nuevos buques al caladero (INAP, 1999; Madaria, 1999; Fratini, 2006; OPP, 2009). Como resultado, el gobierno nacional resolvió no otorgar nuevos permisos para la pesca de esta especie. Otro caso preocupante era del calamar, cuya extracción aumentó once veces durante el cuatrienio 1976-1979 para luego desplomarse un 72,40\% entre ese último año y 1989 (Cuadro 3). 


\section{REFORMAS ESTRUCTURALES, EXTRANJERIZACIÓN MASIVA, SOBRE-PESCA Y COLAPSO BIOLÓGICO: EL PERÍODO NEOLIBERAL (1990-2001)}

Organizado en función del Consenso de Washington -un decálogo de políticas de ajuste estructural elaborado e impuesto por Estados Unidos, el FMI y el Banco Mundial-, el modelo neoliberal aplicado en Argentina (1990-2001) impuso un conjunto de reformas estructurales basadas en la liberalización comercial y financiera, la privatización masiva de empresas públicas, el meteórico endeudamiento externo, la apertura importadora, la desregulación económica, la apertura indiscriminada al capital extranjero, la implementación del Plan de Convertibilidad ${ }^{3}$, la flexibilización laboral y la desindustrialización. Como resultado, el nuevo patrón de acumulación privilegió el comercio internacional, la lógica financiera cortoplacista y especulativa, las extraordinarias rentas asociadas a las privatizaciones y la explotación extranjerizada de los recursos naturales (Frechero, 2013). Estas políticas decantaron en el surgimiento y expansión de un nuevo ciclo extractivo-exportador, favoreciendo tanto la apropiación privada como la extranjerización a muy bajo costo de los recursos implicados.

Obstando los (incipientes pero evidentes) síntomas de sobreexplotación del caladero, toda la política pesquera se reestructuró para alentar la 'globalización' del sector. A partir de 1992, el Estado nacional autorizó a los armadores argentinos a arrendar -vía el régimen de charter- buques poteros extranjeros a casco desnudo para la captura del calamar. Esta política, que originalmente regía por un plazo de tres años y luego sería prorrogada reiteradamente, benefició a barcos japoneses y, en menor medida, españoles, taiwaneses y coreanos, que así lograron operar legalmente dentro de la ZEE y gozar del derecho a ser considerados como buques de bandera nacional, quedando al mismo tiempo exentos de procesar las capturas en tierra (Madaria, 1999; OPP, 2009).

Sin embargo, la apertura al capital extranjero se tornó verdaderamente masiva recién en 1994, cuando comenzó a regir el denominado Acuerdo Sobre las Relaciones en Materia de Pesca entre la República Argentina y la Comunidad Económica Europea. Permitiendo el acceso a una de las reservas mundiales de merluza más importantes del mundo, dicho acuerdo benefició sobre todo a España, cuya flota de buques de gran tonelaje y fuerte equipamiento tecnológico se hallaba en gran parte inactiva luego de la depredación practicada en las costas africanas del Mar Mediterráneo. Orientado a satisfacer las preferencias de la demanda europea de pescado congelado, el convenio establecía que, durante un quinquenio -con la posibilidad de prorrogarse dos años más-, Argentina se comprometía a despachar 250.000 tn anuales de pescado al mercado europeo y permitir que hasta una tercera parte de las capturas contempladas en el acuerdo fuera obtenida por buques de bandera comunitaria. Dadas las restricciones vigentes para el otorgamiento de nuevas licencias de pesca para la merluza común, las operaciones debían realizarse con permisos ya emitidos, razón por la cual el Estado profundizó la experiencia iniciada durante los años setenta y ochenta fomentando la fusión entre firmas pesqueras europeas y nacionales a través de la formación de UTE's y sociedades mixtas, permitiendo además las operaciones individuales de buques y armadores comunitarios y las radicaciones empresariales (Cepparo et al, 2008). En ese esquema, los buques cedentes de las licencias debían ser desguazados y sustituidos por barcos dotados de igual capacidad de captura (Cóccaro et al, 2000; Fratini, 2006).

Como resultado, la Argentina absorbió el $44 \%$-esto es, 72 unidades, sobre un total de 164- de las embarcaciones de gran tamaño que España transfirió entre 1991 y 1997 a 22 países (Muleiro, 2000). Colocando parte de su flota congeladora excedentaria en aguas nacionales, los empresarios ibéricos lograron así controlar los dos extremos clave del circuito: captura y comercialización (Pradas, 2006). En consecuencia, si en 1989 la flota pesquera 'argentina' estaba integrada por 228 buques -de los cuales 146 eran fresqueros y 82 eran congeladores-, en 1997 pasó a estar constituida por 414 unidades, con notable primacía de los barcos procesadores congeladores (282 naves) (Bertolotti et al., 2001).

El acuerdo con la Comunidad Económica Europea se desarrolló en términos muy diferentes a los estipulados. Dado que los buques que ingresaron al caladero eran congeladores, su capacidad de captura 620 tn de registro bruto promedio- era un $92,86 \%$ superior al tonelaje nominal de los barcos que cedieron sus licencias (Muleiro, 2000) ${ }^{4}$. Asimismo, los cupos de captura iniciales fueron reiterada y sistemáticamente ampliados por el Estado nacional para así completar la capacidad ociosa de las bodegas y evitar el lucro cesante de buques financiados por bancos alemanes y españoles (Gómez Lende, 2015). Por añadidura, los permisos de pesca se multiplicaron fraudulentamente vía diversos mecanismos. Numerosos buques argentinos cedieron sus licencias pero continuaron explotando el recurso clandestinamente comprando permisos caducos, utilizando licencias obtenidas en remates de empresas en quiebra y ampliando ilegalmente sus concesiones de captura (Cóccaro et al., 2000; Fratini, 2006).

De ahí que en 1997 se reportara el pico máximo de desembarques de toda la historia pesquera argentina: 1.343.219,5 toneladas ${ }^{5}$, más del doble de lo extraído en 1990 (583.291,8 toneladas) (Cuadro 4). Como resultado, la pesca marítima pasó a representar el $2 \%$ del PBI, en tanto que el sesgo exportador de la actividad se tornó mucho más pronunciado. Destinadas sobre todo a España, Japón, Brasil y Estados 
Unidos, las remesas pesqueras argentinas rondaron los 1.000 millones de dólares, absorbiendo entre el 65\% y el $90 \%$ de las capturas y superando a actividades de larga tradición exportadora como el complejo cárnicobovino (Madaria, 1999; Fratini, 2006; OPP, 2009). A lo largo de la década, el esfuerzo pesquero se concentró básicamente en cuatro especies -merluza común, calamar, polaca y merluza de cola-, las cuales representaron entre el $75 \%$ y el $83 \%$ de los desembarques. Indudablemente, las pesquerías más dinámicas correspondieron, por un lado, a la merluza común -cuyas capturas se incrementaron un 57,90\% entre 1990 y 1997- y, por el otro, a la merluza de cola y el calamar -cuyos desembarques aumentaron 9,6 y 14,5 veces en igual período, respectivamente- (Cuadro 4). Paralelamente, el langostino se afianzó como principal rubro de exportación (OPP, 2009), pese al relativamente magro volumen extraído.

Cuadro 4. Volumen de desembarques de pescado en puertos marítimos (en toneladas y porcentajes).

Principales especies y años seleccionados. Argentina, 1990-2001

\begin{tabular}{|l|c|c|c|c|c|c|}
\hline \multicolumn{1}{|c|}{ Especie } & $\mathbf{1 9 9 0}$ & $\mathbf{\%}$ & $\mathbf{1 9 9 7}$ & $\mathbf{\%}$ & $\mathbf{2 0 0 0}$ & $\mathbf{\%}$ \\
\hline Abadejo & $34.775,0$ & 5,96 & $25.245,0$ & 1,88 & $15.183,1$ & 1,77 \\
\hline Anchoíta & $13.357,4$ & 2,29 & $25.197,6$ & 1,88 & $12.157,5$ & 1,42 \\
\hline Caballa & $3.770,2$ & 0,65 & $10.468,3$ & 0,78 & $10.122,1$ & 1,18 \\
\hline Calamar illex & $\mathbf{2 8 . 3 4 1 , 3}$ & $\mathbf{4 , 8 6}$ & $\mathbf{4 1 1 . 7 2 3 , 4}$ & $\mathbf{3 0 , 6 5}$ & $\mathbf{2 7 9 . 0 6 7 , 6}$ & $\mathbf{3 2 , 5 5}$ \\
\hline Corvina blanca & $6.565,8$ & 1,13 & $26.108,0$ & 1,94 & $5.295,5$ & 0,62 \\
\hline Langostino & $\mathbf{9 . 6 2 9 , 3}$ & $\mathbf{1 , 6 5}$ & $\mathbf{6 . 4 8 1 , 9}$ & $\mathbf{0 , 4 8}$ & $\mathbf{3 7 . 1 5 0 , 0}$ & $\mathbf{4 , 3 3}$ \\
\hline Merluza común & $\mathbf{3 7 1 . 9 7 5 , 9}$ & $\mathbf{6 3 , 7 7}$ & $\mathbf{5 8 7 . 3 4 7 , 6}$ & $\mathbf{4 3 , 7 3}$ & $\mathbf{1 9 5 . 1 7 1 , 4}$ & $\mathbf{2 2 , 7 6}$ \\
\hline Merluza de cola & $\mathbf{4 . 3 5 2 , 7}$ & $\mathbf{0 , 7 5}$ & $\mathbf{4 1 . 7 8 7 , 2}$ & $\mathbf{3 , 1 1}$ & $\mathbf{1 2 3 . 9 2 5 , 6}$ & $\mathbf{1 4 , 4 5}$ \\
\hline Pescadilla & $9.664,4$ & 1,66 & $24.132,9$ & 1,80 & $9.463,3$ & 1,10 \\
\hline Polaca & $\mathbf{3 2 . 8 4 4 , 9}$ & $\mathbf{5 , 6 3}$ & $\mathbf{7 9 . 9 3 7 , 3}$ & $\mathbf{5 , 9 5}$ & $\mathbf{6 1 . 3 1 3 , 7}$ & $\mathbf{7 , 1 5}$ \\
\hline Raya & 468,1 & 0,08 & $12.129,9$ & 0,90 & $13.289,0$ & 1,55 \\
\hline Sub-total & $\mathbf{5 1 5 . 7 4 5 , 0}$ & $\mathbf{8 8 , 4 2}$ & $\mathbf{1 . 2 5 0 . 5 5 9 , 1}$ & $\mathbf{9 3 , 1 0}$ & $\mathbf{7 6 2 . 1 1 1 , 2}$ & $\mathbf{8 8 , 8 9}$ \\
\hline Resto & $\mathbf{6 7 . 4 7 4 , 5}$ & 11,58 & $92.660,4$ & 6,90 & $95.257,7$ & 11,11 \\
\hline Total & $\mathbf{5 8 3 . 2 9 1 , 8}$ & $\mathbf{1 0 0 , 0 0}$ & $\mathbf{1 . 3 4 3 . 2 1 9 , 5}$ & $\mathbf{1 0 0 , 0 0}$ & $\mathbf{8 5 7 . 3 6 8 , 9}$ & $\mathbf{1 0 0 , 0 0}$ \\
\hline
\end{tabular}

Fuente: elaboración personal sobre la base de Sánchez, Navarro y Rozycki (2012).

Empujando a algunas especies al borde de la extinción, la excesiva presión sobre el recurso, la fijación por parte del Estado de cupos superiores a los recomendados por el INIDEP y la constante trasgresión de los mismos por parte de las firmas pesqueras ${ }^{6}$ inexorablemente condujeron al colapso biológico del caladero. El caso más paradigmático correspondió a la merluza común, cuya biomasa cayó un $28 \%$, disminuyendo en promedio casi un $60 \%$ respecto de los guarismos registrados en 1986 . Su capacidad reproductiva -esto es, la proporción de ejemplares adultos responsables por la regeneración de la especie- retrocedió a menos del $30 \%$, límite por debajo del cual comienza el riesgo de extinción. Finalmente, la sensible disminución de su talla media intensificó el esfuerzo pesquero, obligando a los buques a capturar mayor número de ejemplares para mantener constantes sus volúmenes de producción (INAP, 1999; OPP, 2009). A pesar de las constantes alertas emitidas por los expertos, recién en 1997 el gobierno argentino reconoció la crisis del recurso, primero estableciendo cupos más reducidos -los cuales fueron ampliamente rebasados- y luego declarando la Emergencia Pesquera Nacional y poniendo fin al convenio con la CEE. En 1999 el Estado nacional decretó una veda parcial para la merluza en aguas patagónicas, para posteriormente disponer la prohibición total y por tiempo indeterminado para la pesca de esa especie en el área comprendida entre los paralelos $43^{\circ}$ y $47^{\circ}$-es decir, hasta Puerto Deseado-, llevando las operaciones de la flota congeladora al sur del paralelo $48^{\circ}$ y fuera de la ZEE. Sin embargo, ya era tarde. En 2000, por primera vez en cuarenta años la merluza común dejó de liderar los desembarques, a tal punto que su extracción se redujo un 66,67\% respecto de 1997 y su peso relativo sobre las capturas se desplomó del 63,77\% registrado en 1990 al exiguo 22,76\% reportado a finales del Siglo XX (Cuadro 4).

Tanto la veda total inicialmente dispuesta por el Estado nacional como los primeros (y fallidos) intentos de cuotificación del recurso desencadenaron agudos conflictos que fueron representados por el discurso periodístico como una disputa entre distintas localizaciones (Buenos Aires versus Patagonia), tipos de flota (fresquera versus congeladora), orígenes del capital (nacional versus extranjero) y tipo de explotación (intensiva en trabajo versus intensiva en capital). Aunque el conflicto era real -máxime ante el creciente peso en los desembarques alcanzado por los buques congeladores gracias al acuerdo con la $\mathrm{CEE}^{7}$ , ese discurso convenientemente ocultaba el hecho de que varias empresas poseían buques tanto fresqueros como congeladores que operaban simultáneamente en todo el litoral marítimo argentino (Mateo, Nieto y Colombo, 2010).

En Mar del Plata, principal puerto pesquero del país, la flota fresquera -de fuerte especialización merlucera- permanecía casi inactiva, con la consiguiente paralización de las plantas de fileteado debido a la escasez o falta de materia prima. La compleja situación de las numerosas familias que dependían de la 
actividad derivaron en el estallido social de junio 2000, con el saldo de fábricas tomadas, álgidos conflictos entre empresarios y obreros y entre los propios trabajadores, episodios de violencia, depósitos e instalaciones incendiados y represión policial (Colombo, 2014). Como resultado, el gobierno nacional resolvió eximir de restricciones geográficas a los buques fresqueros.

Obligada a pescar en latitudes donde la merluza era escasa, la flota congeladora desplegó entonces una doble estrategia: por un lado, infringió la veda, interponiendo recursos de amparo para continuar operando al norte del paralelo $48^{\circ}$-algunos de ellos validados por jueces patagónicos- (Fratini, 2006; OPP, 2009) e incluso pescando ilegalmente en el área reservada a la flota fresquera; por el otro, reorientó parte de su esfuerzo pesquero hacia otras especies, tal como lo refleja el Cuadro 4, donde se muestra cómo la merluza de cola pasó de tener una incidencia despreciable en 1990 a convertirse en la tercera especie más explotada a finales de esa década, sufriendo durante el cuatrienio 1997-2000 un incremento de las capturas del $197 \%$ que llevó su peso relativo sobre los desembarques del 3,11\% al 14,45\%. El auge de esta pesquería no obedeció sólo a su papel sustituto de la merluza común en el marco de la coyuntura, sino también a la reestructuración de la flota surimera japonesa y noruega con base de operaciones en Ushuaia que, ante el desplome del $40 \%$ de las capturas de polaca entre 1997 y 2000, buscó incorporar a la merluza de cola como nueva especie-objetivo.

Otro caso digno de consideración fue el del calamar, cuya extracción mermó un 32,22\% entre 1997 y 2000, no obstante lo cual continuó explicando la tercera parte del volumen pescado y pasó a liderar los desembarques $(32,55 \%)$ frente a la caída de las capturas de merluza común (Cuadro 4). Esto obedecía a la contradictoria política del Estado nacional, que por un lado declaraba la crisis de la merluza y la emergencia pesquera, pero por el otro paralelamente autorizaba el ingreso al caladero de 27 barcos poteros japoneses mediante un nuevo régimen de licencias (charter) que concedía un cupo de extracción de 65 millones de dólares, reduciendo además el costo de las licencias -lo cual atrajo también a la flota calamarera española y coreana- y habilitando a los buques comunitarios y asiáticos a pescar en aguas internacionales entre los paralelos $45^{\circ}$ y $48^{\circ}$ sur (OPP, 2009). Dado que dicho molusco es uno de los principales alimentos de la merluza, dicha política no contribuyó a la recuperación de esta última especie, como tampoco lo hicieron los nuevos permisos otorgados a buques españoles para la cosecha de langostino ni la autorización a la flota tangonera -la principal involucrada en la pesca incidental de juveniles de merluza- para continuar operando en el área de veda.

Obstando el impulso brindado tanto a la racionalidad extractivista a ultranza como a la creciente extranjerización del recurso, otro rasgo típico de esta fase fue la debilidad regulatoria estatal, en un contexto donde la precariedad de los controles pesqueros no era sino el natural correlato de la implacable avanzada neoliberal y la consiguiente racionalización del aparato burocrático. Basta señalar que, entre 1996 y 1999 , el número de inspectores a bordo se redujo ostensiblemente, pasando de 400 a apenas 27 personas que debían controlar un universo de casi medio millar de embarcaciones (INAP, 1999). Aún así, esta modalidad de vigilancia develó serias irregularidades, como el falseamiento de los partes de pesca presentados por los capitanes y la extracción de especies no permitidas en niveles situados muy por encima de los parámetros tolerados por la legislación vigente para 'fauna acompañante' o 'captura incidental'. Más graves aún eran los masivos niveles de descarte, que sólo en 1996 implicaron que se arrojaran al mar 65.000 toneladas de pescado, en su inmensa mayoría constituidas por ejemplares juveniles de merluza y otras especies que dos años después se habrían convertido en 400.000 toneladas de ejemplares adultos comercialmente explotables (INAP, 1999).

\section{LA CONTINUIDAD DE LA DEPREDACIÓN NEOLIBERAL: EL RÉGIMEN NEO- DESARROLLISTA (2002-2015)}

A comienzos del Siglo XXI, el modelo neoliberal dejó como saldo una brutal crisis socioeconómica, signada por el rápido desplome del PBI, una tasa de desocupación estructural del $21 \%$, más de la mitad de la población inmersa en la pobreza y una cuarta parte sumida en la indigencia. Ante tal pérdida de legitimidad, el péndulo ideológico viró hacia las políticas 'post-neoliberales' y 'neo-desarrollistas' llevadas a cabo por auto-proclamados gobiernos 'progresistas'. Bajo el nuevo régimen, el Estado puso fin al régimen de Convertibilidad, devaluó la moneda, desarrolló mecanismos de captación y apropiación de la renta exportadora e implementó políticas públicas activas de reindustrialización, control del movimiento de capitales financieros y movilidad social ascendente, pero al mismo tiempo afianzó e incluso profundizó gran parte de las reformas estructurales neoliberales, sin atenuar ni la concentración y la extranjerización económica ni la depredación de los bienes naturales (Cortese et al., 2013).

Como resultado, el modelo primario-exportador legado por el neoliberalismo se intensificó durante la etapa (neo)desarrollista para alimentar el meteórico y exponencial crecimiento de China, en un esquema donde nuestro país pasó a desempeñar el doble rol de proveedor de materias primas/alimentos y receptor de las inversiones/importaciones industriales del gigante asiático. Esto no vino a significar entonces la 
'salida' del neoliberalismo, sino más bien la fase superior de un nuevo ciclo de re-colonización (Machado Aráoz, 2013) donde los conceptos de 'extractivismo' y 'desarrollo' dejarían de ser antagónicos, contradictorios y mutuamente excluyentes para fusionarse en un meta-relato emancipatorio donde confluían el boom primario-exportador, el crecimiento económico, la estabilidad política, el interés soberano y la redistribución del ingreso (Svampa, 2012; Seoane y Algranati, 2013; Burchardt \& Dietz, 2014).

Así, la racionalidad pesquera extractivista y depredadora a ultranza continuó e incluso se agudizó. En 2004, y pese a que el INIDEP informaba acerca de una incipiente recuperación del recurso gracias a la prohibición vigente, el Estado nacional puso fin a la veda de la merluza liberando de toda restricción a la flota congeladora, permitiéndole además operar en el área adyacente a la ZEE (milla 200-201). Por añadidura, el gobierno consolidó la reforma pesquera ensayada por el neoliberalismo implementando en 2009 el llamado Sistema de Cuotas Individuales Transferibles de Captura (SCITC), un régimen originalmente formulado a finales de la década de 1990. El SCITC otorga a cada buque una cuota porcentual del cupo correspondiente a cinco especies (polaca, merluza común, merluza de cola, merluza negra y vieira) por un lapso de 15 años, basándose sobre todo en el historial promedio de capturas alcanzado por cada buque durante el período 1989-1996. En la práctica, esto implica premiar justamente a aquellas empresas que en el pasado más contribuyeron a la depredación del recurso y a la dramática disminución de la biomasa explotable (Villemur, 2006; Osiroff, 2009; Lerena, 2013). Paralelamente, también imprime renovados bríos a la lógica extractivista, toda vez que penaliza con la reducción de cupos a quienes hayan pescado el $90 \%$ o menos de la cuota asignada durante dos años consecutivos o tres alternados.

Es importante destacar que tales permisos pueden transferirse libremente, venderse, arrendarse e incluso hipotecarse. Esto ha aumentado los niveles de concentración del capital y generado numerosas irregularidades, como la ampliación de los cupos iniciales vía el usufructo de cuotas de buques inexistentes, inactivos, hundidos o desguazados y las transferencias parciales de permisos, que además de ser ilegales implican que tanto el barco cedente como el buque receptor operen como si dispusieran del cupo completo.

Los gobiernos 'progresistas' también alentaron la primacía de la flota congeladora y la extranjerización del sector. En base a estadísticas oficiales (Sánchez, Navarro y Rozycki, 2012; MA, 2018), puede colegirse que la participación de los buques congeladores sobre los desembarques de la flota industrial aumentó del 60,7\% registrado en 2003 al 66,1\% en 2015. Este avance fue impulsado por resoluciones sancionadas en 2007, mediante las cuales el gobierno recortó el cupo anual para la extracción de merluza a buques fresqueros para favorecer a los grandes barcos-factoría (Maturana, 2008). Asimismo, se afianzó la presencia en el caladero de la flota española, rusa, japonesa, estadounidense, canadiense, uruguaya, chilena, inglesa, panameña, china, coreana, noruega y neozelandesa. Por añadidura, si bien la mayoría de estos buques es nominalmente comandada por un capitán argentino -como lo dispone la legislación vigente-, las capturas son dirigidas ilegalmente por un tripulante extranjero ${ }^{8}$.

A pesar de la crisis pesquera de finales del Siglo XX, la flota industrial continuó creciendo, llegando a estar integrada por casi 600 embarcaciones, de las cuales 210 correspondían al sector congelador (Telam, 2016). El consiguiente aumento del esfuerzo pesquero y la resultante presión sobre el recurso se tradujeron primero en un ostensible incremento de los desembarques durante los primeros años neodesarrollistas, para luego desembocar durante la década siguiente en una caída casi tan aguda como la reportada a finales del Siglo XX. En efecto, las capturas crecieron un 23,9\% durante el cuatrienio 20032006, pasando de un piso de 842.722,5 toneladas a perforar el techo del millón de toneladas; posteriormente, se redujeron un 35,6\% entre 2006 y 2012 para finalmente estabilizarse en torno a las 700.000 toneladas (Cuadro 5). Expresado de otro modo, la dinámica de los desembarques pesqueros marítimos durante esta fase no hizo más que replicar matizadamente el ciclo verificado durante la etapa neoliberal, con la particularidad de que, a partir de 2012, las capturas se han situado siempre en niveles inferiores a los registrados en 2000, año de la peor crisis pesquera argentina. 
Cuadro 5. Volumen de desembarques de pescado en puertos marítimos (en toneladas y porcentajes). Principales especies y años seleccionados. Argentina, 2003-2015

\begin{tabular}{|l|c|c|c|c|c|c|c|c|}
\hline Especie & $\mathbf{2 0 0 3}$ & $\mathbf{\%}$ & $\mathbf{2 0 0 6}$ & $\mathbf{\%}$ & $\mathbf{2 0 1 2}$ & $\mathbf{\%}$ & $\mathbf{2 0 1 5}$ & \% \\
\hline Abadejo & $14.604,6$ & 1,73 & $20.588,1$ & 1,92 & $10.111,7$ & 1,46 & $5.238,3$ & 0,68 \\
\hline Anchoíta & $28.500,1$ & 3,38 & $31.384,8$ & 2,92 & $15.433,8$ & 2,23 & $14.410,7$ & 1,88 \\
\hline Caballa & $5.036,5$ & 0,60 & $6.080,5$ & 0,57 & $20.794,1$ & 3,00 & $18.269,8$ & 2,38 \\
\hline Calamar illex & $\mathbf{1 4 1 . 0 3 0 , 8}$ & $\mathbf{1 6 , 7 4}$ & $\mathbf{2 9 2 . 0 7 8 , 6}$ & $\mathbf{2 7 , 2 0}$ & $\mathbf{9 4 . 9 8 3 , 7}$ & $\mathbf{1 3 , 7 3}$ & $\mathbf{1 2 6 . 6 7 0 , 9}$ & $\mathbf{1 6 , 5 0}$ \\
\hline Corvina blanca & $11.553,9$ & 1,37 & $26.789,7$ & 2,49 & $37.782,3$ & 5,46 & $31.358,7$ & 4,09 \\
\hline Langostino & $\mathbf{5 2 . 9 0 1 , 5}$ & $\mathbf{6 , 2 8}$ & $\mathbf{4 4 . 4 0 5 , 3}$ & $\mathbf{4 , 1 4}$ & $\mathbf{7 9 . 9 2 6 , 9}$ & $\mathbf{1 1 , 5 5}$ & $\mathbf{1 4 2 . 7 9 6 , 2}$ & $\mathbf{1 8 , 6 0}$ \\
\hline Merluza común & $\mathbf{3 3 6 . 5 1 2 , 8}$ & $\mathbf{3 9 , 9 3}$ & $\mathbf{3 5 5 . 6 1 7 , 6}$ & $\mathbf{3 3 , 1 2}$ & $\mathbf{2 5 7 . 9 8 1 , 4}$ & $\mathbf{3 7 , 2 8}$ & $\mathbf{2 6 6 . 2 5 8 , 8}$ & $\mathbf{3 4 , 6 8}$ \\
\hline Merluza de cola & $\mathbf{9 7 . 7 9 7 , 4}$ & $\mathbf{1 1 , 6 0}$ & $\mathbf{1 2 4 . 6 3 8 , 4}$ & $\mathbf{1 1 , 6 1}$ & $\mathbf{5 9 . 5 9 4 , 9}$ & $\mathbf{8 , 6 1}$ & $\mathbf{5 0 . 4 6 8 , 9}$ & $\mathbf{6 , 5 7}$ \\
\hline Pescadilla & $6.709,0$ & 0,80 & $15.351,5$ & 1,43 & $15.213,7$ & 2,20 & $16.897,6$ & 2,20 \\
\hline Polaca & $\mathbf{4 4 . 5 8 4 , 2}$ & $\mathbf{5 , 2 9}$ & $\mathbf{3 1 . 2 9 2 , 2}$ & $\mathbf{2 , 9 1}$ & $\mathbf{8 . 3 7 8 , 8}$ & $\mathbf{1 , 2 1}$ & $\mathbf{1 3 . 8 3 0 , 9}$ & $\mathbf{1 , 8 0}$ \\
\hline Raya & $17.472,9$ & 2,07 & $23.625,3$ & 2,20 & $15.168,4$ & 2,19 & $19.007,5$ & 2,48 \\
\hline Sub-total & $\mathbf{7 5 6 . 7 0 3 , 7}$ & $\mathbf{8 9 , 7 9}$ & $\mathbf{9 7 1 . 8 5 2 , 0}$ & $\mathbf{9 0 , 5 1}$ & $\mathbf{6 1 5 . 3 6 9 , 7}$ & $\mathbf{8 8 , 9 3}$ & $\mathbf{7 0 5 . 2 0 8 , 3}$ & $\mathbf{9 1 , 8 9}$ \\
\hline Resto & $86.021,8$ & 10,21 & $101.902,7$ & 9,49 & $76.616,0$ & 11,07 & $62.260,9$ & 8,11 \\
\hline Total & $\mathbf{8 4 2 . 7 2 5 , 5}$ & $\mathbf{1 0 0 , 0 0}$ & $\mathbf{1 . 0 7 3 . 7 5 4 , 7}$ & $\mathbf{1 0 0 , 0 0}$ & $\mathbf{6 9 1 . 9 8 5 , 7}$ & $\mathbf{1 0 0 , 0 0}$ & $\mathbf{7 6 7 . 4 6 9 , 2}$ & $\mathbf{1 0 0 , 0 0}$ \\
\hline
\end{tabular}

Fuente: elaboración personal sobre la base de Sánchez, Navarro y Rozycki (2012) y MA (2018).

Repitiendo la tendencia de la fase anterior, la principal especie-objetivo continuó siendo la merluza común, que a lo largo del período explicó alrededor de un tercio de los desembarques. Otro caso digno de consideración era el del calamar, cuya extracción se duplicó en apenas un cuatrienio (2003-2006), pasando a dar cuenta de más de la cuarta parte del volumen capturado. Sin perjuicio de lo anterior, la pesquería más dinámica fue la del langostino, cuya cosecha se triplicó entre 2003 y 2015, aumentando su incidencia sobre los desembarques del 6,28\% al 18,60\% y convirtiéndose así en la tercera especie más explotada. En su conjunto, cuatro especies -las tres previamente mencionadas y la merluza de cola- explicaban alrededor del $75 \%$ del esfuerzo pesquero (Cuadro 5).

El nuevo colapso biológico del recurso pesquero no se hizo esperar. Según informes del INIDEP, al sur del caladero la biomasa total y reproductiva de la merluza común eran un $71,4 \%$ y un $80 \%$ inferiores a las de 1986, alcanzando uno de sus valores históricos más bajos y situándose un tercio por debajo del límite que garantiza la renovación del recurso. Al norte, la biomasa total se hallaba un $40 \%$ por debajo del nivel crítico, verificándose durante el período 1986-2009 sendas reducciones del 78\% para el stock global y del $87 \%$ para la biomasa reproductiva. Como resultado, el recurso era entre un $50 \%$ y un $70 \%$ más escaso que un cuarto de siglo atrás (AGN, 2011; 2016; DPN, 2011).

A raíz de la nueva crisis, en 2008 el Estado nacional redujo los cupos de captura para la merluza común, lo cual desencadenó agudas convulsiones sociales en Mar del Plata, Madryn, Ushuaia y Deseado. Sin embargo, a partir de entonces su política pesquera sería tan contradictoria como durante la década de 1990. El gobierno argentino continuó estableciendo cupos de captura superiores a los valores recomendados por el INIDEP y toleró que los buques infringieran sistemáticamente esos límites; de hecho, entre 2000 y 2010 la captura real de merluza se situó, en promedio, un 77\% por encima de los niveles permitidos. Asimismo, en 2008 desactivó los dispositivos DISELA II y DEJUPA, que permitían la fuga de ejemplares juveniles, legitimando así una situación de hecho, dado que las empresas pesqueras y los armadores navieros contravenían la normativa y se negaban a utilizarlos (AGN, 2011). Por añadidura, a finales de 2009 el Estado nacional dejó sin efecto la prohibición de capturar más del 10\% de individuos juveniles sobre el volumen extraído y derogó los controles de tallas en puerto (DPN, 2011; AGN, 2016).

Como consecuencia, la crisis se agravó, tal como lo demuestra la caída del 25,12\% de los desembarques de merluza común reportada entre 2003 y 2015 (Cuadro 5). Recién durante el bienio 20132014 la situación de este recurso mejoró, aunque siempre verificándose una excesiva presión sobre la población juvenil de merluza y stocks inferiores al umbral biológico de referencia (AGN, 2011; 2016; DPN, 2011). Ese caso no era el único. La propia FAO alertaba que el caladero argentino se hallaba en situación preocupante, considerando como agotadas o sobre-explotadas a más de la mitad de las 16 especies evaluadas, entre ellas la merluza común, la merluza negra, el calamar y la polaca (DPN, 2011), recurso este último cuyas capturas se desplomaron ininterrumpidamente a lo largo de todo el período $-68,98 \%$ entre 2003 y 2015-. Cabe señalar que este fenómeno se hizo también extensivo a la merluza de cola, que había comenzado a suplantar a la polaca como especie-objetivo de la flota surimera: de hecho, entre 2006 y 2015 sus desembarques disminuyeron un 59,50\% (Cuadro 5).

En el caso específico del calamar, y a pesar de que su extracción se había reducido un $67,48 \%$ entre 2006 y 2012 (Cuadro 5), el Estado nacional prosiguió con su política de entrega del recurso al capital extranjero, otorgando en 2013 sendos permisos a 20 buques poteros chinos y algunas naves taiwanesas y niponas para que operaran dentro de la ZEE. Reglamentado mediante un régimen charter cuya duración oscila entre 10 y 30 años, este sistema no significó otra cosa que un retorno al antiguo modelo que, durante la década de 1990, privilegió a la flota calamarera japonesa (Lerena, 2013). Más recientemente, el INIDEP y la Auditoría General de la Nación advirtieron acerca de la excesiva presión ejercida sobre las especies 
pertenecientes al denominado 'variado costero', considerando al gatuzo, al pez palo, al lenguado, al besugo, a la pescadilla y a la raya en situación de vulnerabilidad o peligro crítico, según el caso (AGN, 2015).

A pesar de esta situación, el boom exportador asociado a la racionalidad extractivista a prosiguió sin pausa. Sumando en promedio más de 1.500 millones de dólares anuales y constituidas en su mayoría (76\%) por el langostino, el calamar y la merluza común, las exportaciones pesqueras pasaron a representar el 95\% del volumen extraído (DEP, 2016a; Telam, 2016; Lerena, 2017). Sólo seis países -España, China, Estados Unidos, Japón, Italia y Brasil- absorbían el $70 \%$ de esas remesas, secundados por Holanda, Alemania, Francia, Bélgica, Europa oriental, Camerún, Nigeria, Congo y Corea del Sur (DEP, 2016a; AGN, 2015). En este sentido, la única diferencia apreciable respecto de la política pesquera neoliberal fue la imposición de derechos de exportación al sector situados en el orden del 10\% para el pescado congelado a bordo y el $5 \%$ para el pescado fresco procesado en tierra. Lejos de implicar la apropiación pública de una parte sustancial de la renta extractivo-exportadora, estas exiguas retenciones fueron licuadas por los reintegros otorgados a las exportaciones por puertos patagónicos, que en 2015 se situaron en valores que oscilaban entre el $8 \%$ y el $13 \%$ del valor comercializado.

Otrora abundante, el recurso ha sido esquilmado para satisfacer las preferencias de los mercados internacionales, determinando que, pese a sus bajos niveles de consumo $-4,5 \mathrm{~kg}$./año per cápita-, el mercado interno sufra episodios crónicos de desabastecimiento, obligando recurrir a las importaciones para compensar esa escasez; de hecho, el volumen de las compras argentinas de pescado y mariscos al exterior creció siete veces entre 1990 (6.113 toneladas) y 2015 (43.014 toneladas) (DEP, 2016b). Como resultado, las flotas extranjeras y sus socios locales le arrebatan recursos alimenticios a nuestro país para drenarlos al mercado mundial, agotando la biomasa disponible y obligando a la población nacional a pagar precios prohibitivos por el magro remanente.

Otra grave problemática agudizada durante el régimen neo-desarrollista es el descarte que, según los cálculos más conservadores, trepó de las 65.000 toneladas/año a un volumen que fluctuaba entre 70.000 y 100.000 toneladas anuales. No obstante, las cifras reales eran mucho mayores. Sólo en el caso de la merluza común, el descarte comprobado en 2007 superó las 82.000 toneladas, e informes más recientes del INIDEP indicaban que cada año se desechan entre 52.000 y 108.000 toneladas de dicha especie (AGN, 2011; DPN, 2011; Telam, 2016; Lerena, 2017). Según el Banco Interamericano de Desarrollo, las cifras globales rondarían las 140.000 toneladas -esto es, alrededor del 20\% de los desembarques totales, más del doble de la proporción informada por la FAO (2016) a escala mundial-, lo cual equivaldría a admitir que cada año la población argentina es despojada de 1,5 millón de raciones de un costoso alimento de alto valor proteico y nutricional (Gaffoglio, 2017). Vale destacar que cualquiera de las cifras mencionadas rebasa holgadamente el volumen que nuestro país debió importar para satisfacer el magro consumo interno en 2015, año en el que se produjo el pico histórico máximo de compras argentinas de pescado al exterior (DEP, 2016b).

Sin soslayar su extrema gravedad, es importante señalar que el descarte es apenas una de las numerosas irregularidades constatadas en el marco del modelo pesquero neo-desarrollista. En un contexto signado por altos niveles de corrupción corporativa e institucional, eran habituales las operaciones fraudulentas de comercio exterior (contrabando, triangulación de exportaciones, evasión aduanera, etc.), la operación ilegal de buques sin habilitación e incluso el otorgamiento de cupos a embarcaciones que no contaban con el permiso correspondiente. Sólo 80 inspectores debían monitorear a toda la flota industrial, y las escasas balanzas disponibles para pesar las capturas eran provistas por los propios armadores y empresas (AGN, 2011; 2016; Telam, 2016; Franco, 2017; Gaffoglio, 2017). Por añadidura, durante el cuatrienio 2006-2009 la Auditoría General de la Nación comprobó que los volúmenes reales descargados en puerto eran entre un $15 \%$ y un $762 \%$ superiores a los partes de pesca de merluza declarados por cada buque (AGN, 2011). Era habitual en ese sentido la espuria práctica de sub-registrar el peso de los cajones estibados y declarar especies diferentes a las realmente capturadas. Todo este acervo de datos empíricos sugiere, sin duda alguna, una evidente y deliberada connivencia entre debilidad regulatoria y saqueo extractivista.

Mención aparte merece la depredación llevada a cabo, por un lado, por la flota uruguaya y los buques asiáticos y europeos habilitados por el vecino país, y por el otro, por la pesca ilegal o furtiva realizada por barcos extranjeros nómades con bandera de China, Japón y Taiwán que operan en el límite con aguas internacionales (milla 201) y frecuentemente invaden la ZEE, atrayendo a los bancos de calamar y otras especies mediante potentes sistemas de iluminación. Integrada por entre 300 y 500 embarcaciones, esta flota furtiva captura cada año aproximadamente un millón de toneladas (Maturana, 2008; Telam, 2016; Lerena, 2017), es decir, una cifra igual o superior a los desembarques 'legales' contabilizados por las estadísticas oficiales. 


\section{CONCLUSIONES}

Soslayada a menudo por los estudios sobre el modelo extractivista, la pesca marítima contemporánea reúne todas las características que justifican su inclusión en dicha perspectiva de análisis. En principio asociado -a diferencia de los hidrocarburos o los minerales- a la explotación de una biomasa renovable, este uso del territorio revela una configuración material y una dinámica social signadas por una extracción del recurso tan intensiva que, a la postre, genera una constante (y creciente) trasgresión de los umbrales de reproducción biológica del mismo. En el caso argentino, la racionalidad extractivista y depredatoria que incipientemente se insinuó en el sector a mediados de la década de 1940 ha ido afianzándose y expandiéndose sistemáticamente a lo largo de los últimos cuatro decenios, para finalmente convertir a la actividad en lo que hoy día es: una auténtica 'minería pesquera'. Su dinámica de acumulación muestra, en ese marco, cómo formas, funciones, acciones, normas y agentes operan para reducir al territorio a un mero recurso explotable y configurar a los puertos pesqueros en simples colonias-commodities donde (con el indudable beneplácito del Estado) se desarrollan economías destructivas de rapiña y formas de producción y circulación innecesaria cuyas trágicas consecuencias -subordinación y dependencia políticoeconómica, pérdida de soberanía nacional, destrucción ambiental, elevados niveles de conflictividad, etc.no son otra cosa que el precio a pagar para preservar un sesgo exportador a ultranza que tan sólo satisface las necesidades de los países centrales y concentra la riqueza en pocas manos.

En consonancia con la preocupante e inquietante situación mundial actual de la pesca marítima, el caso argentino ilustra cómo, al calor de las cambiantes exigencias del mercado mundial y la división internacional del trabajo, el sector pesquero fue abandonando su condición originariamente artesanal para ir incorporando progresivamente los rasgos del modelo extractivista. Como resultado, lo que comenzó como un episodio breve y efímero de reestructuración de la pesca costera doméstica -la fiebre del tiburónpara responder a las demandas coyunturales generadas por la Segunda Guerra Mundial acabó convirtiéndose en una tendencia estructural y creciente de propagación de una lógica -la pesca industrial a gran escala- diseñada para satisfacer intereses foráneos. Desde el boom y casi extinción de la castañeta durante la década de 1960 para viabilizar la inserción del país en el ciclo pesquero peruano hasta el pico histórico de desembarques y el consiguiente colapso de la merluza a finales del Siglo XX para atender a la demanda europea y asiática, y desde la incorporación masiva de buques fresqueros primero y congeladores después hasta la actual crisis que enfrenta gran parte del caladero argentino, el resultado ha sido invariablemente el mismo: sobre-pesca, especies llevadas al borde de la extinción, extranjerización creciente e imposición del paradigma exportador como prioridad situada por encima del interés común, todos fenómenos activamente respaldados e incluso fomentados por el propio Estado.

Por añadidura, los rasgos más alarmantes del modelo pesquero argentino no sólo se replican, sino que se acentúan en cada ciclo histórico. Otrora supeditados a políticas puntuales (permisos especiales, tratados, acuerdos, etc.), los niveles de extranjerización del recurso y la flota se han agudizado a tal punto que la presencia dentro de la Zona Económica Exclusiva de buques españoles, japoneses, chinos, coreanos, taiwaneses, norteamericanos, rusos, ingleses, noruegos, uruguayos, chilenos y neozelandeses ha dejado de ser la excepción para convertirse en la regla, ora a través de fusiones empresariales, ora vía convenios internacionales y regímenes charter. Asimismo, la dinámica de acumulación del sector se ha tornado cada vez más ajena al mercado interno, como lo demuestra el hecho de que las exportaciones hayan pasado de absorber cerca de la mitad de las capturas a acaparar hoy día casi la totalidad de la extracción.

Antaño reservada a casos puntuales o alcanzando niveles incipientes, la sobreexplotación (y consecuente crisis) del recurso ha acabado haciéndose extensiva a varias especies, generalizándose a la vez que los ingentes niveles de descarte -equivalentes a la quinta parte de los desembarques de pescado en puerto- se han más que duplicado durante los últimos veinte años para rebasar holgadamente la tasa promedio mundial. Finalmente, mientras que la pesca ilegal realizada en el Mar Argentino por los buques extranjeros nómades se ha naturalizado al punto de extraer una biomasa superior a la explotada por los navíos autorizados -contra el apenas $15 \%$ reportado por las estadísticas internacionales-, la debilidad regulatoria estatal iniciada por el modelo neoliberal y continuada por el (neo)desarrollismo se ha constituido en campo fértil para la consolidación de la pesca marítima como sector atravesado por la irregularidad, el fraude y la corrupción corporativa e institucional en tanto correlatos políticos de (y variables funcionales a) la insaciable voracidad extractivista del capital. 


\section{NOTAS}

1 - Mientras que los barcos fresqueros poseen menos capacidad de captura y almacenamiento, bajos niveles de autonomía operativa y logística (pescan sólo 185 días al año, debiendo pasar al menos 60 días en puerto) y desembarcan las capturas en tierra para su elaboración, los buques congeladores navegan entre 60 y 90 días sin interrupción y pasan sólo 42 días/año en puerto, recorriendo distancias mucho más largas, realizando 305 días de pesca efectiva al año y congelando y procesando las capturas a bordo (Colombo, 2014).

2 - El surimi es una pasta de pescado lavada y empaquetada a bordo, con agregado de agentes criogénicos, muy consumida en Asia, sobre todo en Japón.

3 - El Plan de Convertibilidad fue una política monetarista aplicada entre 1991 y 2001 basada en la paridad nominal entre el peso argentino y el dólar estadounidense.

4 - Cabe destacar que la capacidad de carga de un buque congelador se sitúa, como mínimo, en el orden de las 500.000 toneladas, mientras que la bodega de un barco fresquero alcanza un máximo de 240.000 toneladas.

5 - Es importante señalar que estos guarismos no incluyen la pesca furtiva, la sub-declaración o sub-registro de capturas, el descarte de ejemplares juveniles, las operaciones de la flota uruguaya ni la actividad de los buques extranjeros en la milla 201.

6 - Sobre la base de datos presentados por Colombo (2014), es posible estimar que entre 1993 y 1999 los niveles de sobre-pesca rondaron, en promedio, el 38,3\%, debido a que el volumen extraído durante esos años superó los cupos otorgados en 936.000 toneladas.

7 - En efecto, entre 1989 y 2000 la participación relativa de los buques congeladores sobre los desembarques de la flota pesquera industrial pasó del 41,4\% al 73,2\% (Bertolotti et al., 2001).

8 - Conocida en la jerga del sector como 'el pesca', esta figura es totalmente ajena a las normativas nacionales, siendo legitimada por las empresas con el eufemismo de 'tripulante de confianza', y no estando ni siquiera asentada en el despacho de entrada y salida de los buques. Esta situación se encuentra tan naturalizada que los inspectores y observadores a bordo, las agencias marítimas y todos los organismos vinculados a la operatoria naval saben que en los buques de firmas extranjeras los capitanes argentinos deben consentir la autoridad de facto de 'el pesca' (Osiroff, 2009).

\section{BIBLIOGRAFÍA}

AA. Manual de intereses marítimos nacionales. Buenos Aires: Armada Argentina, s/f. 118 p.

AGN. Informe de gestión: protección del recurso pesquero. Buenos Aires: Auditoría General de la Nación, 2011. 122 p.

AGN. Control de gestión ambiental sobre establecimiento de áreas de veda y límites de captura. Buenos Aires: Auditoría General de la Nación, 2015. 278 p.

AGN. Gestión en relación al establecimiento de captura máxima permisible por especie, derechos de extracción, otorgamiento de permisos de pesca y establecimiento y control de zonas de veda. Buenos Aires: Auditoría General de la Nación, 2016. 78 p.

BARRUTI, S. Malcomidos. Cómo la industria alimentaria argentina nos está matando. Buenos Aires: Planeta, 2013. 464 p.

BERTOLOTTI, M. I.; PIERGENTILI, G.; CABUT, D. El sector pesquero argentino. Investigación Pesquera, Buenos Aires, v. 51, n 2, p. 193-221, 1987.

BERTOlOTTI, M. I.; VERAZAY, G.; ERRAZTI, E.; PAGANI, A.; BUONO, J. La flota pesquera argentina. Evolución durante el período 1968-1998, con una actualización al 2000. El Mar Argentino y sus recursos pesqueros, Buenos Aires, n. 3, p. 9-53, 2001.

BRUNHES, J. La Géographie humaine. Paris: PUF, 1942. 162 p.

BURCHARDT, H-J.; DIETZ, K. (Neo)extractivism - a new challenge for development theory from Latin America. Third World Quarterly, v. 35, n. 3, p. 468-486, 2014.

CEPPARO, M.; GABRIELIDIS, G.; PRIETO, E.; HUERTAS, M. Evolución de la legislación pesquera desde la segunda mitad del Siglo XX. Ciclos de la actividad pesquera en Santa Cruz, Buenos Aires. 2008. Disponible en: http://bdigital.uncu.edu.ar/1143 (acceso en: 03 de sep. 2014).

CÓCCARO, J.; LE BAIL, J.; GÓMEZ, O.; BOETTO, A. La minería pesquera ¿argentina? IN: II ENCUENTRO INTERNACIONAL HUMBOLDT. Mar del Plata, 2000.

COLOMBO, G. De la revolución productiva a la crisis de la merluza: El conflicto social en la industria pesquera marplatense. Años 1989-2001. 2014. 480 p. Tesis de Doctorado en Historia - Universidad Nacional de La Plata. 
CORTESE, C.; DEL C. LLANO, María; y equipo. El modelo «productivo con inclusión social»: una modalidad de redistribución de ingresos manteniendo la concentración de la riqueza. Revista Confluencia, Mendoza, v. 13, p. 3-117, 2013.

DEP. Exportaciones pesqueras: Comportamiento de los principales mercados 2015. Buenos Aires: Ministerio de Agroindustria de la Nación-Dirección de Economía Pesquera, 2016a. 31 p.

DEP. Exportaciones e importaciones pesqueras 2015. Buenos Aires: Dirección de Economía Pesquera, 2016b. 46 p.

DPN. Informe: Implicancias ecológicas, sociales y económicas de la pesca no sustentable en el Mar Argentino: el caso de la merluza. Buenos Aires: Defensor del Pueblo de la Nación, 2011. 180 p.

FAO. El estado mundial de la pesca y la acuicultura 2012. Roma: Organización de las Naciones Unidas para la Alimentación y la Agricultura, 2012. 251 p.

FAO. El estado mundial de la pesca y la acuicultura 2016. Roma: Organización de las Naciones Unidas para la Alimentación y la Agricultura, 2016. 226 p.

FÉLIZ, M. Neoextractivismo, neodesarrollismo y proceso de acumulación de capital: ¿superando el ciclo de stop-and-go? Argentina, 2003-2012. In: VII JORNADAS DE SOCIOLOGÍA DE LA UNLP. La Plata: UNLP, 2012.

FRANCO, L. La AGN detectó serias irregularidades en el control de la pesca. Diario Ámbito Financiero, Buenos Aires, 21/11/2017.

FRATINI, S. Causas de la depredación pesquera durante la década de 1990. In: MORINA, J. Neoliberalismo y problemáticas regionales en Argentina. Interpretaciones geográficas. Luján: Universidad Nacional de Luján, 2006. p. 133-147.

FRECHERO, J. Extractivismo en la economía argentina. Categorías, etapas históricas y presente. Estudios Críticos del Desarrollo, Zacatecas, v. III, n. 4, p. 45-82, 2013.

GAFFOGLIO, G. Denuncian que se tiran al mar 140 mil toneladas de pescado fresco al año. Diario Clarín, Buenos Aires, 04/02/2017.

GIARRACCA, N.; TEUBAL, M. Las actividades extractivas en la Argentina. In: GIARRACCA; TEUBAL, M. Actividades extractivas en expansión: ¿reprimarización de la economía argentina? Buenos Aires: Antropofagia, 2013. p. 159-172.

GÓMEZ LENDE, S. La pesca marítima en la Argentina (1989-2013): un caso de (neo)extractivismo y acumulación por desposesión. Revista Geográfica del IPGH, Ciudad de México, n. 156, p. 53-96, 2015. GOTTMANN, J. The evolution of the concept of territory. Information sur les Sciences Sociales, París, v. 14, n. 2, p. 29-47, 1975.

GUDYNAS, E. Estado compensador y nuevos extractivismos. Las ambivalencias del progresismo sudamericano. Nueva Sociedad, Buenos Aires, v. 237, p. 128-146, 2012.

GUDYNAS, E. El desarrollo revisitado desde los debates sobre los extractivismos y sus alternativas. 2015. Disponible en: https://www.uhu.es/IICIED/pdf/2_1_extract.pdf (acceso en: 15 de ago. 2017).

HAESBAERT, R. Território e multiterritorialidade: um debate. Geographia, Niterói, v. 9, n. 17, p. 1945, 2008.

INAP. El sector pesquero marplatense: una aproximación diagnóstica del actual y futuro escenario ante la emergencia de la Ley de Pesca. Buenos Aires: Instituto Nacional de la Administración Pública, 1999. $92 \mathrm{p}$.

LERENA, C. El gobierno nacional sin política pesquera (2013). 2013. Disponible en: http://liganaval.org.ar/noticias/informe pesca.pdf (acceso en: 03 de sep. 2014).

LERENA, C. La crisis estructural del sector pesquero y una ley de pesca (24.922) inadecuada. 2017. Disponible en: http://netnews.com.ar/nota/810-La-crisis-estructural-del-sector-pesquero-y-una-ley-depesca-24922-inadecuada (acceso en: 04 de feb. 2018).

LÓPEZ, R. La pesca en la República Argentina durante el año 1952. Revista del Museo Municipal de Ciencias Naturales y Tradicional, Mar del Plata, v. I, p. 26-49, 1954.

MA. Desembarques por especie, puerto, mes y flota (años seleccionados). Ministerio de Agroindustria. 2018. Disponible en: http://www.agroindustria.gob.ar/sitio/areas/pesca_maritima/desembarques/ (acceso en: 04 de feb. 2018).

MACHADO ARÁOZ, H. Orden neocolonial, extractivismo y ecología política de las emociones. Revista Brasileira de Sociología da Emoção, Paraiba, v. 12, n. 34, p. 11-43, 2013.

MADARIA, E. El sector pesquero argentino. Informe general. Buenos Aires: Universidad Católica Argentina, $1999.87 \mathrm{p}$.

MARX, K. El capital. México, D. F.: Fondo de Cultura Económica, 1968. 520 p.

MASSARD-GUILBAUD, G. Historiadores, geógrafos y la relación hombre-medio en Francia: de Vidal de la Blache a los programas interdisciplinares de finales del siglo XX. Áreas Revista Internacional de Ciencias Sociales, Murcia, n. 35, p. 15-25, 2016. 
MATEO, J. Cosechando el mar en lanchas amarillas. La expansión de la pesca costera marplatense (19391963). Anuario IEHS, Tandil, n. 19, p. 305-335, 2004.

MATEO, J. Sembrando anzuelos para tiburones. Las demandas vitamínicas de la II Segunda Guerra Mundial y el desarrollo de la pesca comercial marítima en Argentina (1943-1952). Boletín del Instituto de Historia Argentina Dr. Emilio Ravignani, Buenos Aires, n. 29, p. 119-150, 2006.

MATEO, J.; NIETO, A.; COLOMBO, G. Precarización y fraude en la industria pesquera marplatense: el caso de las 'cooperativas' de fileteado de pescado. Estado actual de la situación y evolución histórica de la rama 1989-2010. Buenos Aires: CEIL-PIETTE, 2010. 120 p.

MATEO, J.; YURKIEVICH, G. Estrategias de la anchoíta en un mar de tiburones. Las pymes conserveras marplatenses durante la valorización financiera (1975-2006). Trabajos y Comunicaciones, La Plata, n. 36, p. 141-164, 2010.

MATURANA, R. Colapso de los recursos pesqueros. Tribuna de Periodistas. 2007. Disponible en: https://periodicotribuna.com.ar/3225-colapso-de-los-recursos-pesqueros.html (acceso en: 04 de feb. 2018). MATURANA, R. Pesca y corrupción. Tribuna de Periodistas. 2008. Disponible en: https://periodicotribuna.com.ar/3549-pesca-y-corrupcion.html (acceso en: 04 de feb. 2018).

MH-INDEC. Complejos exportadores 2016. Buenos Aires: Ministerio de Hacienda-Instituto Nacional de Estadística y Censos, 2017. 15 p.

MULEIRO, V. Saqueo en alta mar. Diario Clarín, Buenos Aires, 09/04/2000.

OCEAN SENTRY.ORG. Sobre pesca: la muerte de los océanos. 2009. Disponible en: http://www.oceansentry.org/es/sobrepesca-la-muerte-de-los-oceanos/ (acceso en: 05 de feb. 2018).

OPP. Economía-Sector pesquero. Un recurso económico no convencional. Buenos Aires: Observatorio de Políticas Públicas, 2009. 95 p.

OSIROFF, S. La pesca en Tierra del Fuego. Río Grande: Universidad Tecnológica Nacional, 2009. 124 p.

PORTILLO RIASCOS, L. Extractivismo clásico y neoextractivismo. ¿Dos tipos de extractivismos diferentes? Revista de la Facultad de Ciencias Económicas y Administrativas, Nariño, v. 15, n. 2, p. 11-29, 2014.

PRADAS, E. Un acercamiento a la problemática pesquera marplatense. Buenos Aires: El Mensajero, 2006. 127 p.

RUIZ ACOSTA, M. La devastación socioambiental del capitalismo en la era del Antropoceno. Mundo Siglo XXI, revista del CIECAS-IPN, México, D. F., n. 32, v. IX, p. 33-46, 2014.

SÁNCHEZ, R.; NAVARRO, G.; ROZYCKI, V. Estadísticas de la pesca marina en la Argentina. Evolución de los desembarques (1898-2010). Buenos Aires: Ministerio de Agricultura, Ganadería y Pesca de la Nación, Dirección Nacional de Planificación Pesquera, 2012. 264 p.

SANTOS, M. Espaço e método. São Paulo: Nobel, 1992. 88 p.

SANTOS, M. A natureza do espaço. Técnica e tempo, razão e emoção. São Paulo: Hucitec, 1996. 257 p.

SANTOS, M.; SILVEIRA, M. O Brasil. Território e sociedade no início do século XXI. Rio de JaneiroSão Paulo: Record, 2001. 473 p.

SEOANE, J. Modelo extractivo y acumulación por despojo. In: SEOANE, J.; TADDEI, E.; ALGRANATI, C. Extractivismo, despojo y crisis climática. Desafíos para los movimientos sociales y los proyectos emancipatorios de Nuestra América. Buenos Aires: Herramienta-El Colectivo-GEAL, 2013. p. 21-40. SEOANE, J.; ALGRANATI, C. El sabor amargo del crecimiento económico: la expansión del modelo extractivo entre 2003 y 2007. : SEOANE, J.; TADDEI, E.; ALGRANATI, C. Extractivismo, despojo y crisis climática. Desafíos para los movimientos sociales y los proyectos emancipatorios de Nuestra América. Buenos Aires: Herramienta-El Colectivo-GEAL, 2013. p. 61-82.

SICCARDI, E. El problema del tiburón en la economía pesquera e industrial. In: ACTAS DEL PRIMER CONGRESO NACIONAL DE PESQUERÍAS MARÍTIMAS E INDUSTRIAS DERIVADAS. Mar del Plata, 1950.

SVAMPA, M. Extractivismo neodesarrollista, gobiernos y movimientos sociales en América Latina. Problèmes d'Amérique Latine, París, n. 80, s/p, 2011.

SVAMPA, M. Consenso de los commodities y megaminería. Revista América Latina en Movimiento, Quito, n. 473, a. XXXVI, p. 5-8, 2012.

TELAM. La pesca, su añejo universo de problemas y los primeros pasos del nuevo gobierno. Agencia Telam. 2016. Disponible en: http://www.telam.com.ar/notas/201611/169460-pesca-anejo-universoproblemas-primeros-pasos-nuevo-gobierno.html (acceso en: 05 de feb. 2018).

VILLEMUR, J. La pesca marítima en la Argentina. Quinquenio 2001-2005. Boletín del Centro Naval, Mar del Plata, n. 815, p. 497-514, 2009. 